\title{
Uncharted biodiversity in the marine benthos: the void of the smallish with description of ten new Platyhelminth taxa from the well-studied North Sea
}

\author{
Werner Armonies* ${ }^{*}$
}

\begin{abstract}
Most of our planet's biodiversity is still unknown, particularly in the sea. Although around the island of Sylt in the North Sea, the small zoobenthos (meiofauna) has been studied intensively since the 1950s, repeating previous surveys revealed an unexpected wealth of new species in addition to the 330 species of free-living microturbellarians (non-parasitic Platyhelminthes) already known from this area. Extrapolation from well-known to less-known habitat types suggests that a total of some 520 Platyhelminth species should be expected around this island, about 670 in the North Sea ecoregion, and 830 in the 'Northern European Sea' ecoprovince. Assuming that the other biogeographic provinces of the planet harbour a similar diversity, a total of some 20,000 marine microturbellarian species is estimated for the global shelf zones. Less than $10 \%$ of these are known by now. As a contribution to fill that gap, ten new taxa are described: Coelogynopora minuta n. sp., Coelogynopora sopottehlersae n. sp., Cirrifera paraculeata n. sp., Boreocelis fragilis n. sp., Postbursoplana noldti n. sp., Promesostoma wehrenbergi n. sp., Ptyalorhynchus oculatus n. sp., Acrorhynchides canaliculatus n. sp., Dactyloplana n. gen., and Dactyloplana tridigitata n. sp.
\end{abstract}

Keywords: Benthos, Diversity, Species richness, North Sea, Platyhelminthes

\section{Introduction}

Meiofauna is a largely neglected component of the marine benthos [1]. These are the benthic organisms small enough to pass through $1 \mathrm{~mm}$ meshes but large enough to be retained on a $63 \mu \mathrm{m}$ screen. The small size makes them difficult to handle, and investigators need high-quality microscopes and expertise in morphology and taxonomy. That is why marine meiofauna is rarely studied, and if so, most studies concentrate on copepods or nematodes [2], which have a hard skin (the carapace in copepods and a cuticle in nematodes) that keeps their body shape during fixation. Therefore, they can be studied in a preserved state, which allows for short field sampling campaigns and for the evaluation of the fixed

\footnotetext{
*Correspondence: Werner.Armonies@awi.de
}

Alfred-Wegener-Institut Helmholtz-Zentrum für Polar- und

Meeresforschung, Wattenmeerstation Sylt, Hafenstr. 43, 25992 List,

Germany materials over a nearly unrestricted amount of time at a distant laboratory. Other taxa, such as Platyhelminthes, have a soft skin and a body without any skeletal elements. They usually shrink to a bulky mass during fixation, which complicates species identification because the natural position of internal organs can no longer be seen. These soft-skinned species are best determined alive, while anatomical details may require serial sections of individually fixed organisms [3]. The need for live observation requires prolonged field trips and access to a field station. Because of these complications, soft-bodied taxa are rarely studied and the studied areas are usually close to one of the few accessible field stations. Consequently, distributional maps show a few hot spots surrounding the field stations with large interspaces never studied. Outside Europe, these interspaces may include entire continents. 
One of the hot spots in meiofaunal research is the island of Sylt in the eastern North Sea, where field access is offered by Wadden Sea Station Sylt (now part of AlfredWegener Institute for Polar- and Marine Research, and formerly of Biologische Anstalt Helgoland). By area, sandy beaches are the most important habitat in the supratidal and sandy flats in the intertidal of this island. Concentrating on a single sandy beach area next to List harbour, the interstitial micro- and meiofauna taxa have been studied one by one by several investigators since the 1960s. Altogether $>650$ meiofaunal species were recorded from this beach, which exceeded the number of macrofaunal species by an order of magnitude [4].

Most meiofauna live in the system of pores left between the sand grains of the sea floor. The size of these pores depends on the granulometric sediment composition. As the sediment becomes finer, organisms need to become smaller or more slender to fit the narrow pores. Therefore, sediment composition is a key factor for meiofauna. At the same time, sediment composition correlates with hydrographic conditions such as current velocity and wave height, which in turn affect sedimentary organic matter uptake and hence food availability for small fauna
[5]. A second key factor for meiofauna is tidal level, which relates to many physical factors, including the variability of temperature and salinity (low in the subtidal and increasingly higher towards the supratidal) and sediment sorting (mostly well-sorted in the subtidal and increasingly heterogeneous towards the supratidal). These two key factors can be used to define habitat types in the coastal zone (Fig. 1), which may be further refined, e.g. by including habitat modifying species such as seagrasses.

The sandy beach next to List harbour mentioned above only represents the sandy inter- and supratidal section of habitats available around Sylt. Other habitat types were only studied for Platyhelminthes, including salt marshes $[6,7]$, mud flats [8], and sand flats with lugworm (Arenicola marina) burrows $[9,10]$. As a result of these studies, the Platyhelminthes inhabiting inter- and supratidal habitats are thought to be well known on the island of Sylt. Compared to that, infra- and subtidal habitats were only marginally studied. Wehrenberg and Reise [11] gave an overview on Platyhelminth species density and abundance, and Noldt [12, 13] described subtidal Kalyptorhynchia. At that time, Xenacoelomorpha (Acoela and Nemertodermatidae) were still included in the phylum
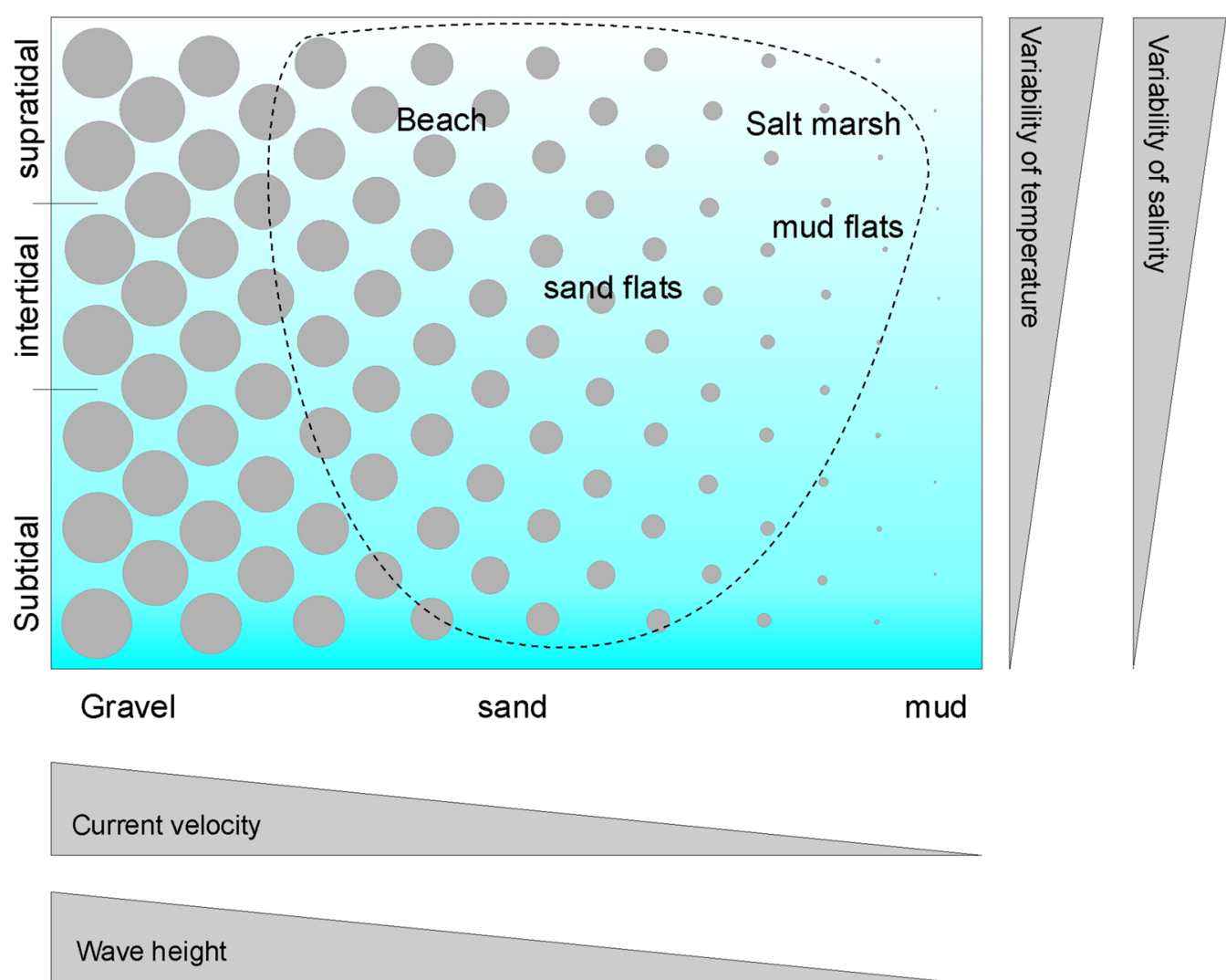

the island of Sylt. Further explanations in the text 
Platyhelminthes, until genetic analyses revealed a distant position in the phylogenetic system [14]. By now, it seems they are most likely the sister group of Nephrozoa [15, 16]. Platyhelminth species numbers in this paper always exclude Xenacoelomorpha and therefore are not comparable to older references where Xenacoelomorpha were still included.

As a result of the high number of studies on a wide range of habitats, some 330 species of microturbellarians (i.e. the phylum Platyhelminthes without parasitic Neodermata and macrofaunal Polycladida) were recorded from the Island of Sylt. This is roughly equivalent to $20 \%$ of the world-wide known marine microturbellarian species. No other locality of the world is known to harbour such a richness of Platyhelminth species. Nevertheless, there are still more species around this small island. Resampling of the beach next to List harbour $40-50$ years after the first studies on meiofauna revealed 20 out of 220 Platyhelminth species previously not recorded [17]. Thus, in spite of the many studies on meiofauna in the past (summarised in [4]) species richness in this beach was still incompletely recorded. The present study gives first results from re-sampling of the subtidal sediments. In the past, the subtidal was studied in a far lower intensity than higher tidal levels. Accordingly, the percentage of new species detected was higher than in the better-studied higher tidal levels. Some of the new species are described below in the taxonomic part of the results.

As the number of species known from this small island was already high, how many more species can be expected in the Sylt area? And, as such a small area already harbours so many species, how many microturbellarian species might exist in the $99 \%$ of the world's coastline that was never studied for these tiny organisms, so far? Due to a lack of knowledge, these questions presently cannot be answered. But since microturbellarians in the Sylt area are exceptionally well known, we can use these data to perform a sort of mental experiment to get a rough picture on the potential total number of microturbellarian species world-wide in shallow coastal waters. This is done in three steps: (1) to get an idea of local species richness around the island of Sylt, accumulative species numbers over the tidal gradient are calculated for the well-studied upper tidal levels and then extrapolated for the less-known subtidal areas. (2) Around the island of Sylt, sandy sediments predominate while very coarse sand, gravel and fine mud are lacking (Fig. 1), and species preferring these sediment types may not find suitable habitat. Thus, the species recorded around the island of Sylt are only a subset of the regional (North Sea) species pool. Therefore, the estimates for the local (Sylt) species richness are up-scaled for the North Sea ecoregion and the 'Northern European Seas' biogeographic province. (3)
Further up-scaling to a global level yields an idea for the world-wide species richness of marine microturbellarians. The estimate for microturbellarian species richness resulting from this last step suggests that we don't even know the tip of the iceberg, today.

\section{Materials and methods}

The island of Sylt lies in the northern Wadden Sea in the eastern part of the North Sea. This is a shallow coastal region with a chain of barrier islands. The distance from the exposed sandy barrier to the sheltered mainland marshes is about $10 \mathrm{~km}$. Mean tidal range is about $2 \mathrm{~m}$. In the shelter of the barrier islands, about half of the sea floor is exposed during low tides. The sea floor is sedimentary; natural hard substrata are limited to epibenthic mussel- and oyster beds. Sand flats prevail over muddy flats. These are dissected by tidal channels with depths down to $40 \mathrm{~m}$. Of the total water volume, about half is exchanged each tide with the coastal North Sea. From the exposed sandy beaches of barrier islands and shoals of ebb deltas, depth gradually slopes down to $30 \mathrm{~m}$ over a distance of $80 \mathrm{~km}$ offshore. A detailed description of the tidal area around the island of Sylt including its biota and abiotic conditions is provided by Reise [18] and Gätje and Reise [19]. Biogeographically, Sylt belongs to the ecoregion 'North Sea' within the province 'Northern European Seas' of the 'Temperate North Atlantic' realm [20].

The available habitats around Sylt island range from coarse sandy beaches to muddy fine sand (Fig. 1), and most of these habitats have already been studied for microturbellarians. However, species are not restricted to habitat types delimited by man, and the width of distributional ranges varies over species. Accordingly, the species composition of neighbouring habitat types may considerably overlap, and simply adding species numbers over habitats would strongly overestimate local species richness. Therefore, all available literature was screened for the position in the tidal gradient of individual Platyhelminth species using a simple scheme with 7 levels (Table 1). This scheme was constructed because tidal level of the localities was often only verbally described in older studies. The resulting assignment of species with tidal levels is given in Additional file 1. From this table, I accumulated species numbers from the upper supratidal towards the deeper subtidal, i.e. from the well-studied tidal levels to the badly-studied ones. A linear regression line was fitted to the data from the well-studied upper tidal levels. For the lower tidal levels, the deviation of cumulative species numbers from this regression line is treated as an estimate for the number of species still to be detected in the sparsely-studied subtidal around the island. In doing so, I assume that Platyhelminth species richness in the subtidal is similar to inter- and supratidal 
Table 1 Division of the Sylt coastal zone into tidal levels. Plant associations according to Ellenberg [22]

\begin{tabular}{|c|c|}
\hline Tidal level & Description \\
\hline Upper supratidal & $\begin{array}{l}\text { Beach zone higher than } 1 \mathrm{~m} \text { above mean high tide (MHT) level and salt marshes grown with the plant association Armerietum mar- } \\
\text { itimae (ungrazed) or Juncetum gerardii (grazed), also starting about } 1 \mathrm{~m} \text { above MHT. This zone is only flooded during storm tides, } \\
\text { interstitial salinity mostly meso- to oligohaline (18-3 psu) }\end{array}$ \\
\hline Lower supratidal & $\begin{array}{l}\text { Zone between MHT and } 1 \mathrm{~m} \text { above. In salt marshes with the plant association Puccinellietum maritimae. Interstitial salinity mostly in } \\
\text { the polyhaline range (30-18 psu) }\end{array}$ \\
\hline Upper intertidal & $\begin{array}{l}\text { Sand- and mudflats between mid-tide level and MHT. May not be submerged during strong offshore winds. Salinity occasionally } \\
\text { drops to the polyhaline range }\end{array}$ \\
\hline Lower intertidal & Sand- and mudflats between mid-tide level and neap low tide level (NLT). Regularly submerged, salinity rarely beyond ambient level \\
\hline Infratidal & $\begin{array}{l}\text { Zone between NLT and } 1 \mathrm{~m} \text { below mean low tide (MLT); may fall dry during strong offshore winds. Earlier studies often failed to } \\
\text { sample this zone because the actual low water level was too high to reach it from the landward side, or too low to reach it by ship }\end{array}$ \\
\hline Shallow subtidal & Sediments 1-10 m below MLT \\
\hline Deeper subtidal & Water depth $>10 \mathrm{~m}$. In the vicinity of the island this level is only represented by tidal channels with medium to coarse sand \\
\hline
\end{tabular}

habitats. For the subtidal down to $40 \mathrm{~m}$ water depth surrounding the Island of Sylt, this assumption is supported by previous data [21]. However, due to a lack of data from other areas, the assumption can neither be spatially generalized nor be extrapolated towards larger water depths.

The reliability of the estimate for total microturbellarian species richness around the island of Sylt (first step of the estimates on species richness) was checked by evaluating the Platyhelminth species richness and composition in sediment samples collected between July 2015 and April 2018 in the infra- and subtidal zones. This was done by arranging the sites studied during that period $(n=35)$ in chronological order and evaluating the accumulative numbers of species recorded (total of this study and past studies by Wehrenberg and Reise [11], and Noldt $[12,13])$, of species re-discovered (i.e. species already recorded from the Sylt subtidal during the above previous studies), and of new species (previously not recorded from the Sylt subtidal). 'Sites' were sampled in two different ways. In the infratidal accessible from land, 6 replicate cores of $10 \mathrm{~cm}^{2}$ surface area were collected with a hand-held corer. Initially the same sampling scheme was applied in the sites accessible by ship only, by subsampling a larger box-corer with small cores of $10 \mathrm{~cm}^{2}$ surface area (one core per box-corer to avoid pseudoreplication). However in the subtidal, these small cores often contained relatively few Platyhelminth specimens and most species were represented by a single individual only. This is sufficient to record a well-known species but not adequate to study, and potentially describe, new species. Therefore larger cores were collected, i.e. a site was represented by a single box-core grab of $200 \mathrm{~cm}^{2}$ surface area (Fig. 2). The sediment depth sampled was as deep as possible, down to $30 \mathrm{~cm}$ in coarse sand (limited by the length of the box-corer) but only about $10 \mathrm{~cm}$ in fine sand (penetration depth limited by the dense package of sand grains and the weight of the box-corer). Platyhelminthes were separated from the sediment by washing with seawater and anaesthetization with $\mathrm{MgCl}_{2}$-solution [12]. Further details on sampling, localities, and the associated platyhelminth fauna are given in Additional file 1: Table S1.

\section{Results}

Accumulating the number of Platyhelminth species over tidal levels from the well-known supratidal towards the subtidal (Additional file 1: Table S4) showed an almost linear increase in species richness down to neap low tide level (Fig. 3). In the infratidal and below, the slope of the accumulated species numbers graph strongly flattens, as was expected from the lower study intensity.

In the past, 136 Platyhelminth species had been recorded from the Sylt subtidal (Fig. 4, 'known from subtidal'; data in Additional file 1: Table S2). About half of these (74) were re-discovered during this study (Fig. 4, 're-discovered'). In addition, the 35 sites sampled during this study yielded 83 species not previously recorded from the Sylt infra- or subtidal (Fig. 4, 'new for subtidal'). However, many of these 'new' species are known to occur in the intertidal zone and therefore do not increase accumulative species numbers in the infra- and subtidal sections of Fig. 3. Elevations in the level of infra- and subtidal species richness come from 12 species recorded for the first time near Sylt and about 25 new species, some of which are described in the systematic part. In total, this study increased the number of Platyhelminth species recorded from the Sylt infra- and subtidal to 219 (Additional file 1: Table S2).

On average, each site studied revealed two new species, one not previously recorded from the infra- or subtidal zone but known from higher tidal levels, and one species not previously recorded from Sylt or undescribed. The subtidal accumulative species numbers increased rather steadily, with no sign of reaching a 


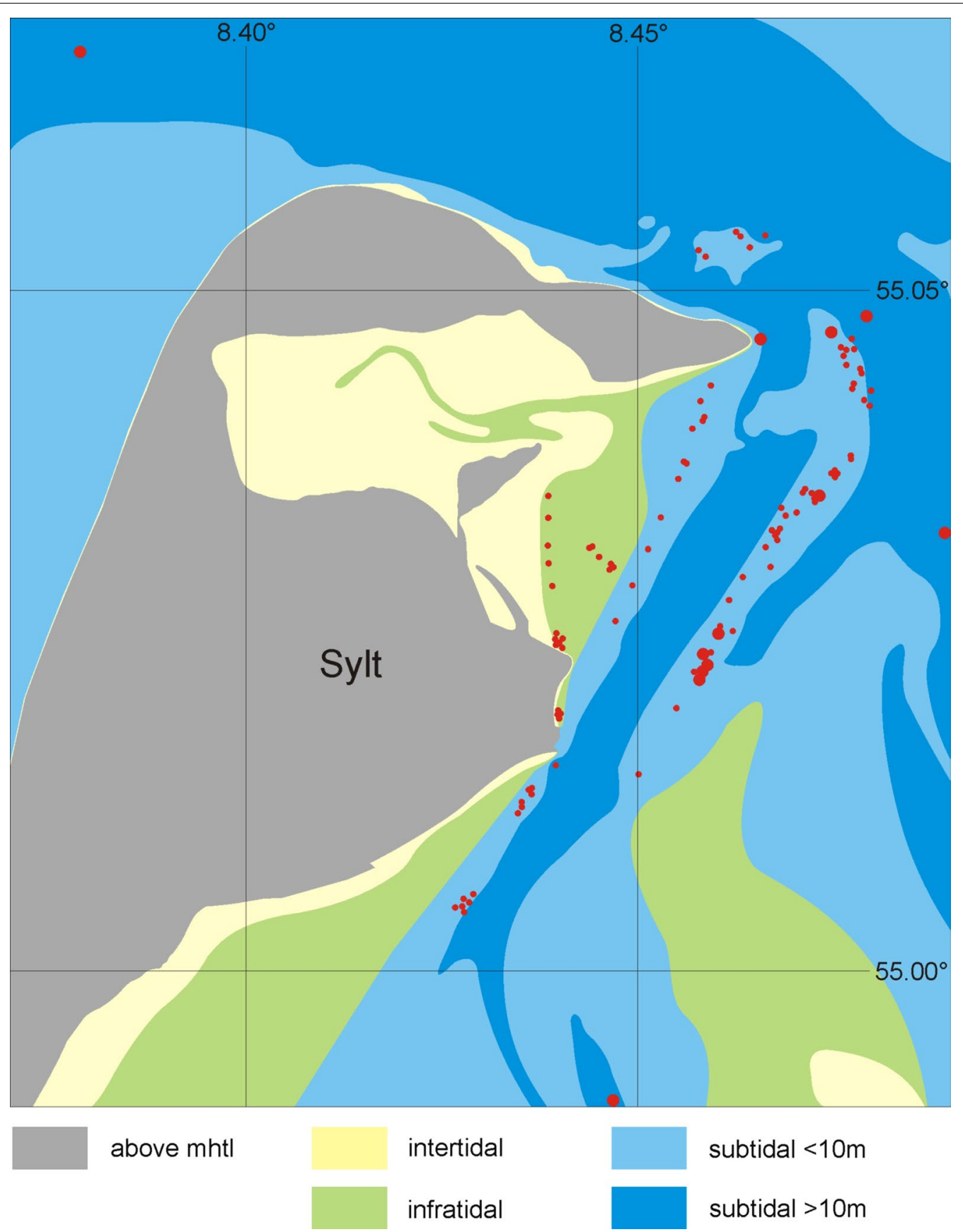

Fig. 2 Sites in the infra- and subtidal near the island of Sylt sampled for Platyhelminths, July 2015-April 2018. Large circles indicate large (200 $\left.\mathrm{cm}^{2}\right)$ cores and small circles small $\left(10 \mathrm{~cm}^{2}\right)$ cores. Two sites in the North Sea west of the island not indicated

saturation level (Fig. 4). With respect to the total species richness around Sylt island, the data of the present study increase the infra- and subtidal parts of the species accumulation graph a bit (solid line in Fig. 3) but it still remains far from the level expected from the extrapolation of the regression line calculated from the better-known tidal levels. From this regression, some 520 species are expected around Sylt Island, which means that further 150 still undetected species of Platyhelminthes may live in the subtidal around Sylt. 


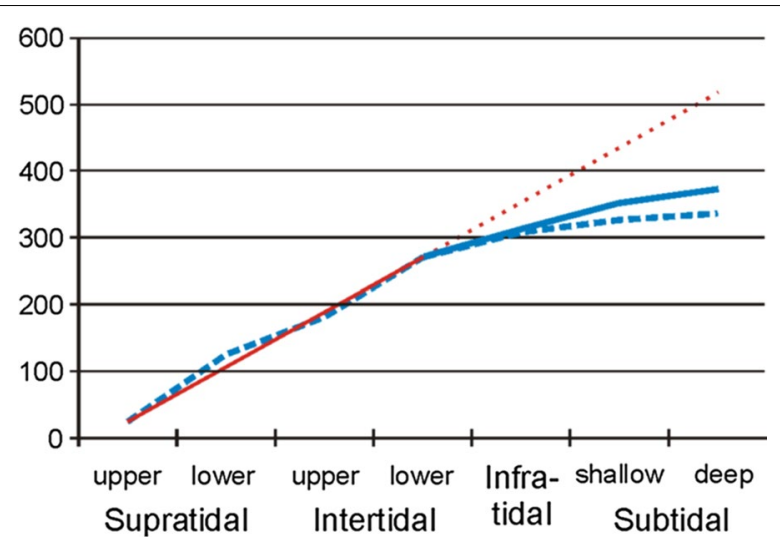

Fig. 3 Number of Platyhelminth species accumulated over the tidal gradient near Sylt island using data until 2015 (broken blue line) and including the current study (solid blue line). The red line gives the linear regression between the upper supratidal and the lower intertidal (solid) and its extrapolation towards the subtidal (dotted)

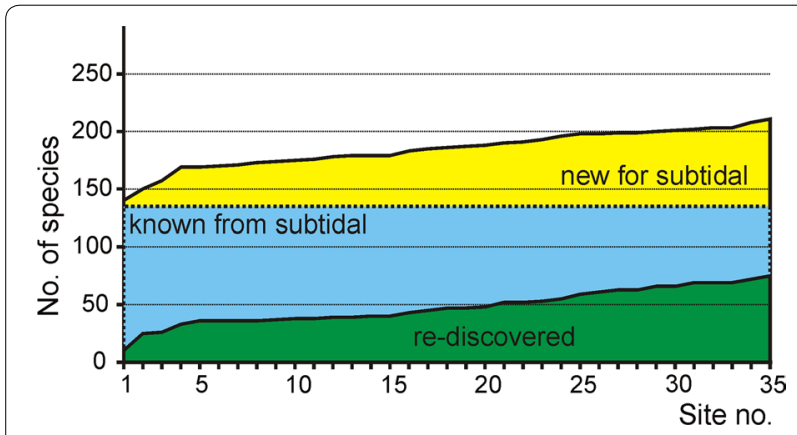

Fig. 4 Number of Platyhelminth species in the Sylt subtidal known until 2015 (blue), re-discovered during this study (green), and new records during this study (yellow)

\section{Discussion}

Including this study, the number of valid Platyhelminth species in the Sylt area has increased to 349 (Additional file 1: Table S3). In addition, some 50 tentatively new species (i.e., species with morphological characters that do not fit any described species) have been recorded in the past but not formally described, so far, mostly because the material was insufficient. These species only 'exist' in unpublished files (drawings and/or photographs) left by Karsten Reise, Christian Wehrenberg, Uwe Noldt, and me. Thus, we already know of 400 species around Sylt. This is not very far from the estimate of a total of 520 species including the sparsely-studied subtidal (from the extrapolation in Fig. 3). However, the 'well-known' inter- and supratidal habitats also still harbour unknown or undescribed species, as exemplified by a previous study [17]. Strictly speaking, the extrapolation only indicates the number of species expected until we reach a level of knowledge in the subtidal that is comparable to the present level of knowledge from higher tidal elevations. The 'real' number of Platyhelminth species around Sylt might be even higher.

In order to get an idea on the total number of microturbellarian species that may exist on a world-wide scale in shallow coastal waters we may now use the above estimates from Sylt to start a mental experiment; this includes spatial extrapolations to scales that have never been studied. Therefore, the results of these extrapolations are merely an educated guess based on a minimum of information. For these spatial extrapolations of Platyhelminth species richness, two numbers will be used for species richness in the Sylt area: (1) a minimum of 349 species, representing the number of currently recorded species that are formally described, and (2) 520 species, representing the estimate derived from Fig. 3.

Usually larger areas include more habitat types than small ones. Currently, 457 species of microturbellarians are known from the North Sea ecoregion (i.e. about 30\% more than from the Sylt area) and 555 from the Northern European Seas province (about 60\% more than from the Sylt area; only valid species excluding synonyms, numina nuda, and species dubiae; Additional file 1: Table S5). These larger areas include habitat types such as soft mud and gravel that are absent (Fig. 1) from Sylt island. Accordingly, the increases in species numbers by $30 \%$ and $60 \%$, respectively, compared to the Sylt area, are assumed to represent the effects of spatial scale and the associated number of habitat types. Estimating the 'true' number of Platyhelminths for theses larger units also needs to include this scaling-effect. Lacking better evidence I used the above percentages derived from the number of species recorded by now. This results in estimates of a total of 676 Platyhelminth species in the North Sea and 832 in the Northern European Sea province, some 50\% more than recorded by now.

The Mediterranean is another biogeographic province where Platyhelminthes have been studied reasonably well to allow for a comparison with the North Sea. The current number of microturbellarian species in the Mediterranean (417 and 445 including the Black Sea, Additional file 1: Table S5) is similar to the Northern European Sea. Together both provinces harbour 862 species, with 138 joint species (roughly $30 \%$ of the total within each province). Thus, a first estimate for the global number of marine microturbellarians comes from the calculation 'number of marine coastal ecoprovinces' on Earth $(=62)$ [20] multiplied by 707 species per ecoprovince (from the estimate 832 for the 'Northern European Seas' minus $15 \%$ for joint occurrences of species in several provinces). 
The result of this estimate is about 44,000 marine microturbellarians on Earth.

However, the Mediterranean and Northern European Seas ecoprovinces are not directly neighbouring but separated by parts of the Lusitanian ecoprovince [20]. Therefore, the species overlap between neighbouring ecoprovinces is likely to be higher than the estimated $30 \%$ in the above example. In fact, we already know that many species colonise $>2$ ecoregions (Additional file 1 : Table S5). Since we have no sufficient data for the percentage of joint occurrences of Platyhelminth species in neighbouring ecoprovinces, two scenarios were calculated. The first scenario assumes species occupy 2 ecoprovinces, on average. The calculation of global marine microturbellarian species numbers is therefore based on half of the species number recorded from, or estimated for, the Northern European Sea ecoprovince. This results in estimates of 17,200 and 25,800 species, respectively, on a global scale. The second scenario assumes species occupy 3 ecoprovinces, on average, and calculations are based on a third of the species recorded from, or estimated for, the Northern European Sea. This results in estimates of 11,500 and 17,200 species of marine microturbellarians in shallow coastal waters on Earth.

These estimates treat species richness in the Northern European Seas representative for all climate zones, which contradicts the general assumption of higher species richness in low than high latitudes [23, 24]. In addition, quaternary glaciations covered most of the North Sea and only left a marginal part of the southern North Sea uncovered by ice [25]. After glacier retreat, the species pool available to repopulate the 'Northern European Seas' ecoprovince may have been exceptionally small. Therefore the estimates for the global number marine microturbellarian species may be rather conservative.

Macrofaunal species richness is far better studied than meiofaunal. Therefore, comparing the relations between macrofaunal species richness in the North Sea and on a global scale offers an alternative way for up-scaling Platyhelminth species richness from the North Sea. With respect to life-style, i.e. predominantly sediment-dwelling species, Nemertea and Polychaeta may be closest to Platyhelminths. Assuming Platyhelminths scale like Polychaetes $(11,757$ species world-wide [26] and 326 in the North Sea [27]) we may expect 16,300-24,100 marine microturbellarian species world-wide. Assuming they scale like Nemertea (1363 species world-wide [26] and 25 in the North Sea [27]), we may expect some 25,00037,500 species globally.

Thus, both ways of estimating microturbellarian species number yield results in a similar order of magnitude ranging between 11,500 and 37,500 species in shallow coastal waters. Throughout this paper, the term 'species' is always used for morphospecies. However, genetically different species may morphologically not be distinguishable from each other (cryptic species), morphologically different species may not be different genetically, or species limits may not be clear by either morphology or genetics in sibling species [28, 29]. Cryptic species may have the strongest effect on the estimates of global Platyhelminth diversity; they may increase the mean number of ecoprovinces occupied by single species und thus turn the estimates for global diversity down. Thus, including molecular and genetic information may yield more precise estimates in the future.

The above estimates for global microturbellarian diversity refer to the shallow coastal regions only because most platyhelminth studies sampled no deeper than $20 \mathrm{~m}$ water depth. Very few samples came from depths down to $200 \mathrm{~m}$ and no platyhelminth species are known from deeper waters. Currently analyses of sedimentary DNA are the only information available for deeper waters. They indicate high platyhelminth species richness from the shelf [30] down to abyssal depth [31].

The situation exemplified here for microturbellarians in principle holds true for the smallish marine benthos in general: all knowledge comes from a few selected sites while most of the world's oceans have never been studied. Presumably, the 'real' numbers of species will exceed the currently known numbers by an order of magnitude for all of the small sized benthic taxa hidden in the sediments. Around the island of Sylt, the relation of species richness of the small sized benthic fauna versus macrozoobenthos currently is 2.4 [32]. With better knowledge on the smallish benthic taxa this relation will increase in the future. In the absence of better data, I hypothesise species richness of the smallish fauna in marine sediments may typically exceed macrozoobenthic species richness (by a factor of 2 or more) on a world wide scale.

\section{Descriptions of new taxa}

Eight of the 25 unknown species recorded in the subtidal sites were frequent enough for a description (Table 2). One of them fits none of the present genera but shares morphological characters with Cheliplana paradoxa Noldt, 1989 which was only preliminarily classified with the genus Cheliplana [12]. Hence, a new genus Dactyloplana is generated for the new species, and Cheliplana paradoxa is re-named as Dactyloplana paradoxa (Noldt, 1989). Among the new species, Acrorhynchides canaliculatus is the only one recorded from inter- and supratidal sites but not from the subtidal, so far. All type material is deposited in the Platyhelminth collection of AWI Wadden Sea Station Sylt. 


\section{Table 2 Systematic classification of the new species}

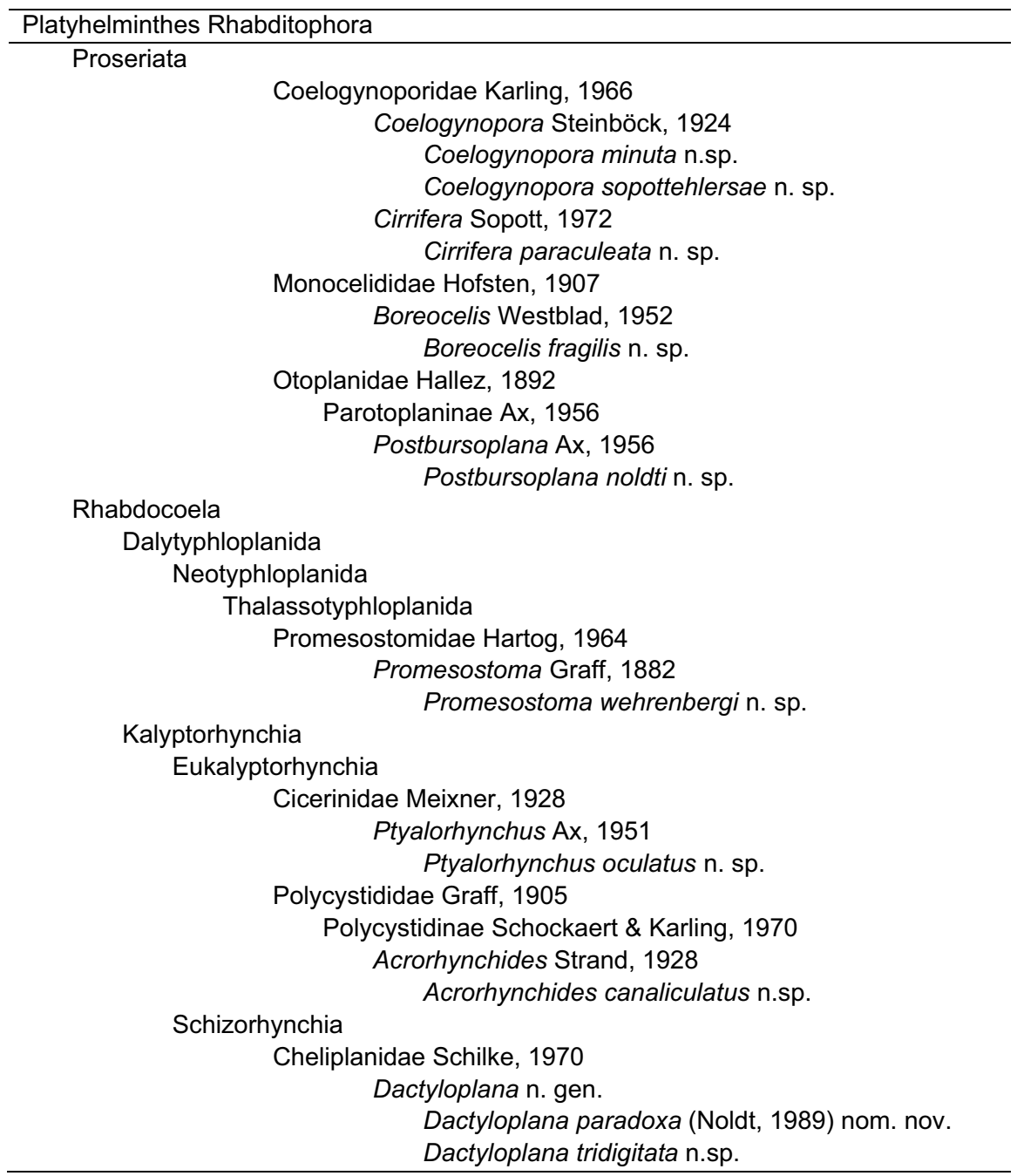

\section{Coelogynopora minuta n. sp. (Fig. 5)}

Localities (1) Type locality: Lister Ley, very fine sand, water depth $10 \mathrm{~m}\left(55.0225^{\circ} \mathrm{N}, 008.4586^{\circ} \mathrm{E}, 1\right.$ individual, 8 Jan 2018). (2) List, infratidal east of Oddewatt. Fine sand, water depth $0.5 \mathrm{~m}\left(55.0240^{\circ} \mathrm{N}, 008.4399^{\circ} \mathrm{E}, 2\right.$ individuals, 6 Oct 2016).

Material Life observations including drawings and photographs. Three whole mounts; one designated holotype (AWI Sylt P2018-103) and two paratypes (AWI Sylt P2018-104 and AWI Sylt P2018-105).

Etymology Compared to other species in the genus the stylet spines are exceptionally small.

Diagnosis Species of Coelogynopora with a cuticular apparatus consisting of a central pipe $(32 \mu \mathrm{m})$ associated with two pairs of longer spines (one more solid and
$32-34 \mu \mathrm{m}$ long, the other very fine and $26-28 \mu \mathrm{m}$ long) and a second group of 8 very short $(21-23 \mu \mathrm{m})$ spines surrounding the central parts in a half circle. No accessory spines.

Description Very slender organisms, preserved 3-3.5 $\mathrm{mm}$ long and $200-250 \mu \mathrm{m}$ in diameter. Live specimens may stretch to $8 \mathrm{~mm}$ with a diameter only slightly wider than the pharynx, i.e. about $150 \mu \mathrm{m}$. Body whitish, without striking epidermal glands or adhesive papillae. The pharynx is spherical and relatively small (diameter $110 \mu \mathrm{m}$ ), in the beginning of the last fifth of the body. In specimens that are not fully stretched the body diameter is markedly narrowed besides the pharynx.

General arrangement of the reproductive system as usual in the genus: the testes follicles form a median row before the pharynx, paired germaries laterally before the pharynx, and vitellaries laterally from the 

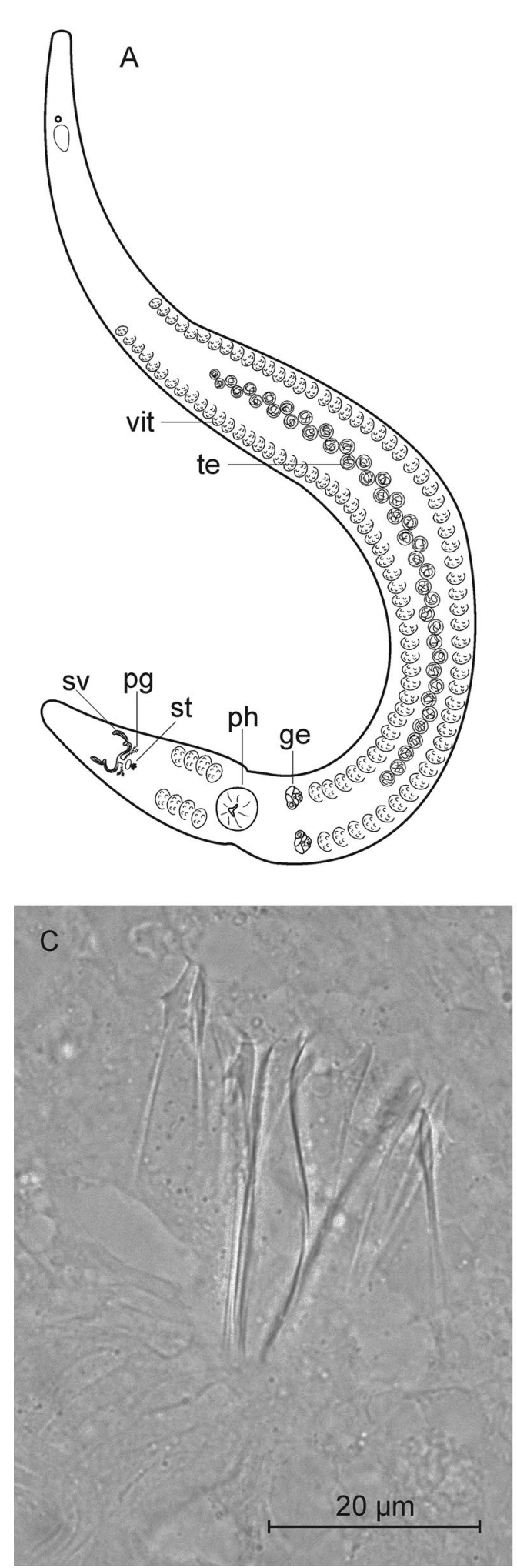

B
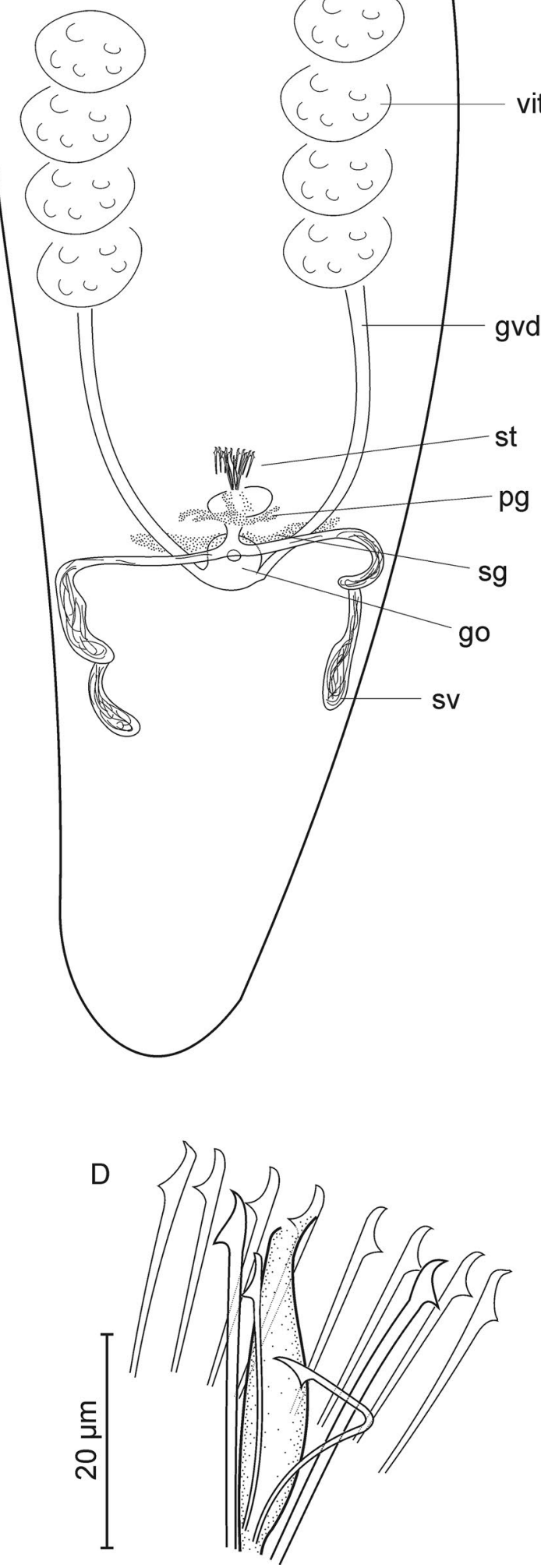

Fig. 5 Coelogynopora minuta. A organization; B rear end; C, D sclerotic genital apparatus 
brain to the copulatory organ, interrupted between the germaries and the caudal end of the pharynx, and copulatory organs half way between the pharynx and the caudal end.

Seminal vesicles paired, laterally in the last tenth of the body. They unite to the common seminal duct that enters the copulatory bulb (prostatic vesicle) together with the distal part of prostatic glands. The ejaculatory duct proceeds to the central pipe of the cuticular apparatus.

The cuticular apparatus consists of a central pipe associated with two pairs of longer spines and a second group of 8 spines surrounding the central parts in a half circle. The central pipe is $32 \mu \mathrm{m}$ long with a small proximal opening $(2 \mu \mathrm{m})$, a bulgy $(6 \mu \mathrm{m})$ middle part, and an obliquely cut distal end, diameter of opening about $3 \mu \mathrm{m}$. The two pairs of longer spines start close to be base of the central pipe but do not seem to be fused to it. One pair of spines is more solid (about $1 \mu \mathrm{m}$ in diameter) and $32-34 \mu \mathrm{m}$ long, the other pair is very slender (diameter about $0.5 \mu \mathrm{m}$ ), slightly bent, and $26-28 \mu \mathrm{m}$ long. The surrounding 8 spines are shorter than the central ones $(21-23 \mu \mathrm{m})$. All spines have a slightly curved tip and a triangular projection $4-5 \mu \mathrm{m}$ from the tip.

The genital opening lies ventrally of the copulatory bulb. Shell glands enter the genital atrium laterally; the germovitelloducts enter laterally at the caudal side. A seminal bursa was not positively detected in live observations.

Discussion Since general morphology is highly similar over the 35 species of the genus described so far, species identity is easiest determined by the composition of the sclerotic genital apparatus. C. minuta is characterized by the small size of both the central pipe and the surrounding spines and by the absence of accessory spines (Table 3 ).

\section{Coelogynopora sopottehlersae n. sp. (Fig. 6)}

Locality Type locality: Lister Ley, a tidal channel in the Wadden Sea near Sylt. Medium sand, water depth $17 \mathrm{~m}$ (55.0322 $\mathrm{N}, 008.4892^{\circ} \mathrm{E} ; 21 \mathrm{Feb} 2018,4$ Individuals).

Material Live observation including drawings and photographs. Four whole mounts, one designated holotype (AWI Sylt P2018-107), three paratypes (AWI Sylt P2018107 to AWI Sylt P2018-110).

Etymology This species is dedicated to Dr. Beate SopottEhlers.

Diagnosis Species of Coelogynopora with a copulatory organ consisting of a central group of spines arranged in two rings that are fused at their base, and 5 pairs of accessory spines positioned frontally of the central spines.
Description Whitish animals, 8-10 mm long, very slender. Frontal end with a few tactile hairs (20-30 $\mu \mathrm{m}$ long). Dermal glands are inconspicuous, irregularly roundish to ovoid, 6-10 $\mu \mathrm{m}$ in diameter, laterally densely packed, dorsally and ventrally in longitudinal rows. Pharynx oriented dorso-ventrally, in the beginning of the last quarter of the body. General organization as usual, with testis follicles in a median row, paired germaries frontally of the pharynx, and lateral vitellaries reaching back to the genital opening.

Seminal vesicles paired, very slender, reaching back to the caudal end. They unite dorsally of the genital opening to a very short common duct with a weak muscular cover that enters the central group of spines in the male copulatory organ. This common duct was not accompanied by prostatic glands and hence is not a prostatic vesicle. The male copulatory organ includes a central group of spines and 5 pairs of accessory spines. The central spines are arranged in two rings that are fused at their base, diameter at base $30 \mu \mathrm{m}$. In the inner one I counted 8 needles of $125 \mu \mathrm{m}$ length that seem to be fused over most of their length, thus forming a slender funnel with a crownshaped tip. The outer ring consists of 16 spines; the dorsal ones are slightly shorter $(110 \mu \mathrm{m})$ and slender with a tapering tip; laterally they become increasingly longer, and the ventral spines are nearly as long as the central spines $(120 \mu \mathrm{m})$ with a broad, flattened tip. Together the outer spines are shaped as an obtuse cone surrounding the central funnel, but they may be spread outwards to give a crown-shaped appearance. The entire central sclerotic element is enclosed in a muscular cover separating the copulatory organ from surrounding tissue; only the very tips of the spines protrude from the muscular cover. The accessory spines form a left and a right group of 5 spines each; their longitudinal position was always frontal of the central spines. The accessory spines are slightly shorter than the central ones $(82-91 \mu \mathrm{m})$ but more solid; they are straight with a slightly curved tip. The accessory spines were surrounded by prostatic secretions, but in live observations the prostatic glands were hardly discernible from the surrounding tissue. Accordingly, it is not clear where the prostatic secretions are released.

Discussion Among the 35 species of Coelogynopora described so far [34] only five have more than one pair of accessory spines and might be closer related with C. sopottehlersae (Table 3). All these species differ in shape, size, and number of the sclerotic components.

The lack of a prostatic vesicle is shared with quite a number of other species, including C. axi, C. solifer, $C$. gallica, C. scalpri, C. sequana, and C. solifer. In these species, prostatic secretions are either released through the accessory spines as seems to be the case in C. axi, or enter the ejaculatory duct besides the spines as in $C$. 
Table 3 Sclerotic elements in the male copulatory organ of Coelogynopora species

\begin{tabular}{|c|c|c|c|c|c|c|}
\hline & \multirow{2}{*}{$\begin{array}{l}\text { Central pipe } \\
\text { Size }(\mu \mathrm{m})\end{array}$} & \multicolumn{3}{|c|}{ Spines in central bundle } & \multicolumn{2}{|c|}{ Accessory spines } \\
\hline & & Number & Size range $(\mu \mathrm{m})$ & Fused & Number & Size $(\mu \mathrm{m})$ \\
\hline C. minuta n. sp. & 32 & 12 & $21-34$ & No & - & - \\
\hline C. sopottehlersae n. sp. & 125 & $8+16$ & $110-125$ & Yes & $2 \times 5$ & $82-91$ \\
\hline C. alata Tajika, 1981 & $f$ & 36 & $72-123$ & Yes & - & - \\
\hline C. axi Sopott, 1972 & - & 10 & $50-69$ & No & 2 & 40 \\
\hline C. biarmata Steinböck, 1924 * & - & $10-12$ & 54-115 & No & 2 & $?$ \\
\hline C. birostrata Tajika, 1978 & $f$ & 6 & $71-83$ & No & 2 & 120 \\
\hline C. brachystyla Karling, 1966 & 120 & 2 & 110 & Yes & - & - \\
\hline C. cassida Sopott-Ehlers, 1985 & 75 & 7 & $18-65$ & Partly & $2 \times 5-6$ & $40-45$ \\
\hline C. cochleare Ax and Sopott-Ehlers, 1979 & - & 30 & $65-100$ & No & 4 & 55 \\
\hline C. coniuncta Tajika, 1978 & 124 & 4 & $104-108$ & No & - & - \\
\hline C. coronata Ax, 2008 & - & $17-19$ & $30-45$ & No & - & - \\
\hline C. distortofolio Sopott, 1972 & - & 4 & $20-50$ & No & 2 & 65 \\
\hline C. erotica Riser, 1981 & - & 6 & $60-90$ & $?$ & $2 \times 12$ & $60-90$ \\
\hline C. faenofurca Sopott-Ehlers, 1992 & $90-100$ & $12-14$ & $30-80$ & No & $2 \times 6-8$ & $50-55$ \\
\hline C. faeroernensis Ax, 2008 & - & 8 & 72 & No & 2 & 57 \\
\hline C. falcaria Ax and Sopott-Ehlers, $1979 *$ & - & 34 & $44-88$ & No & - & - \\
\hline C. forcipis Sopott-Ehlers, 1976 & 60 & 10 & $15-65$ & Partly & $2 \times 3$ & $23-65$ \\
\hline C. frondifera Ax and Sopott-Ehlers, 1979 & - & 20 & $30-60$ & $?$ & - & - \\
\hline C. gallica Sopott-Ehlers, 1976 & - & 11 & $45-80$ & No & 2 & $85-90$ \\
\hline C. gigantea Meixner, 1938 & - & $26-28$ & $?$ & No & - & - \\
\hline C. gynocotyla Steinböck, 1924 & - & 0 & - & - & - & - \\
\hline C. hamulis Sopott-Ehlers, 1980 & - & $8-9$ & $80-105$ & Yes & 2 & $65-70$ \\
\hline C. hangoensis Karling, 1953 * & - & $11-15$ & $80-140$ & No & 2 & $75-95$ \\
\hline C. hymanae Riser, 1981 & - & 8 & $75-105$ & No & 2 & $70-80$ \\
\hline C. juxtaforcipis Riser, 1981 & - & 10 & $25-64$ & Yes & 2 & 90 \\
\hline C. multispina Armonies, 2017 & - & 16 & $70-80$ & No & 2 & $70-75$ \\
\hline C. nodosa Ax and Sopott-Ehlers, 1979 & - & $10-12$ & $70-98$ & $?$ & 2 & 86 \\
\hline C. poaceaglandis Riser, 1981 & - & 12 & $85-120$ & $?$ & 2 & $60-70$ \\
\hline C. scalpri Ax and Sopott-Ehlers, 1979 * & - & 10 & $85-130$ & Partly & 2 & 90 \\
\hline C. schulzii Meixner, 1938 * & - & 9 & $90-135$ & No & 2 & $90-120$ \\
\hline C. sequana Sopott-Ehlers, 1992 * & - & 4 & $75-90$ & Yes & 2 & $60-63$ \\
\hline C. sewardensis Ax and Armonies, 1990 * & - & 10 & $92-168$ & No & 2 & 96 \\
\hline C. solifer Sopott, 1972 & - & 6 & 110 & No & 2 & 80 \\
\hline C. steinboecki Sopott-Ehlers, 1980 & - & 6 & $90-130$ & Yes & 2 & $80-100$ \\
\hline C. tenuiformis Karling, 1966 & - & 8 & $34-41$ & No & 2 & $31-41$ \\
\hline C. tenuis Meixner, 1938 & - & 6 or 8 & 56 & Yes & 2 & 63 \\
\hline C. visurgis Sopott-Ehlers, 1989 & - & $6-8$ & $5-7$ & No & - & - \\
\hline
\end{tabular}

Data based on the original descriptions and *Ax [33]

- Absent

f Central pipe fused with spines

? No or no distinct data

scalpri. However, quite a number of species descriptions lack details on the position of prostatic glands and the existence of a prostatic vesicle. Therefore, the value of these characters for taxonomic purpose currently cannot be evaluated.
Cirrifera paraculeata n. sp. (Fig. 7)

Localities (1) Type locality: Lister Ley, medium sand, water depth $17 \mathrm{~m}\left(55.0322^{\circ} \mathrm{N}, 008.4892^{\circ} \mathrm{E}, 3\right.$ individuals, 21 Feb 2018). (2) List Deep, medium sand, water depth $10 \mathrm{~m}\left(55.0469^{\circ} \mathrm{N}, 008.4748^{\circ} \mathrm{E}, 1\right.$ individual, $\left.26 \mathrm{Mar} 2018\right)$. 


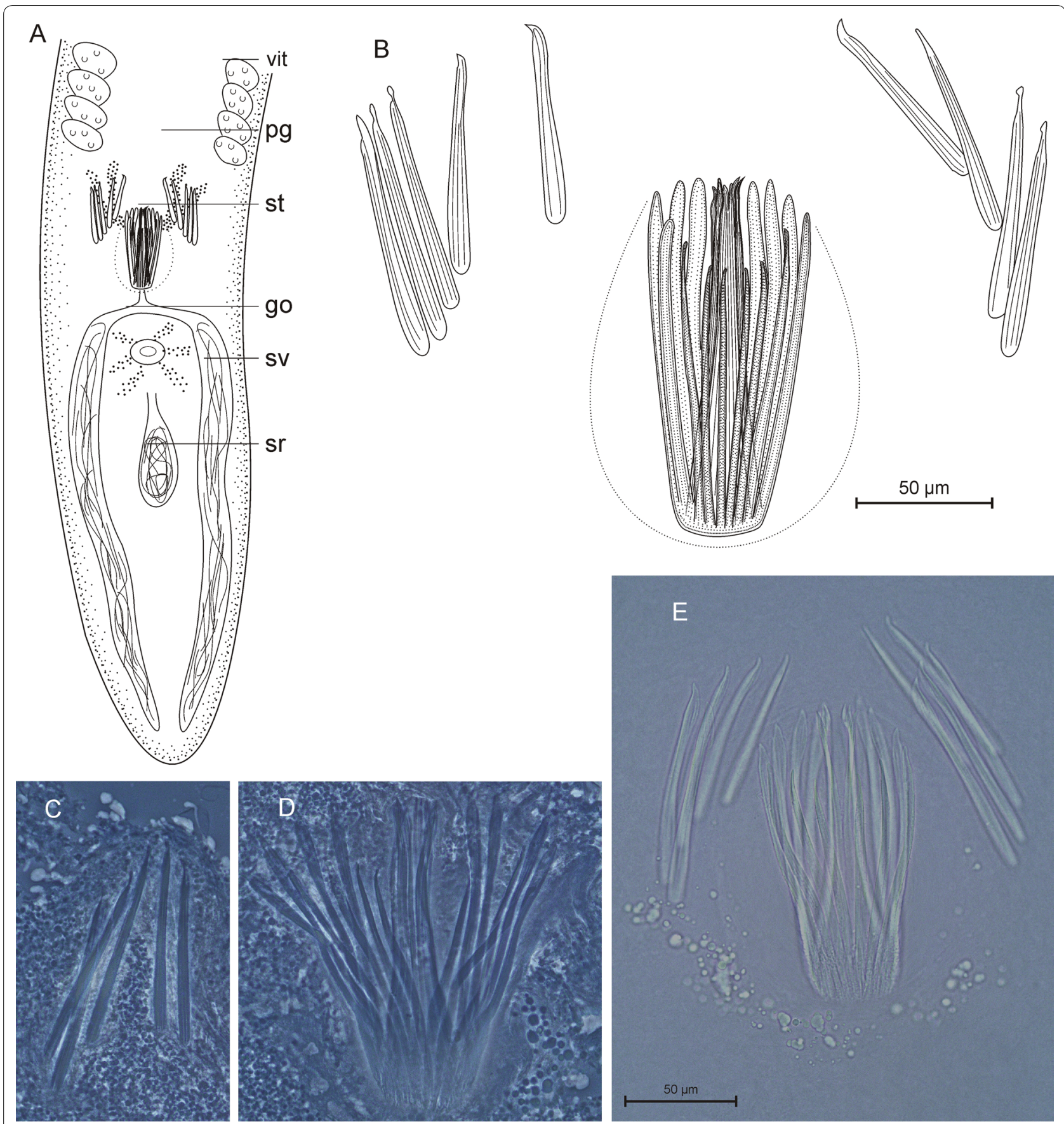

Fig. 6 Coelogynopora sopottehlersae. A organization, rear end. B, E Sclerotic apparatus, gently squeezed. C Accessory spines. D Central group of spines, stronger squeezed

Material Life observations including drawings and photographs. Two whole mounts, one designated holotype (AWI Sylt P2018-101) and one paratype (AWI Sylt P2018-102).
Etymology The species is highly similar to Cirrifera aculeata.

Diagnosis Cirrifera with paired seminal vesicles and a strongly muscular female atrium without spines. Cirrus 


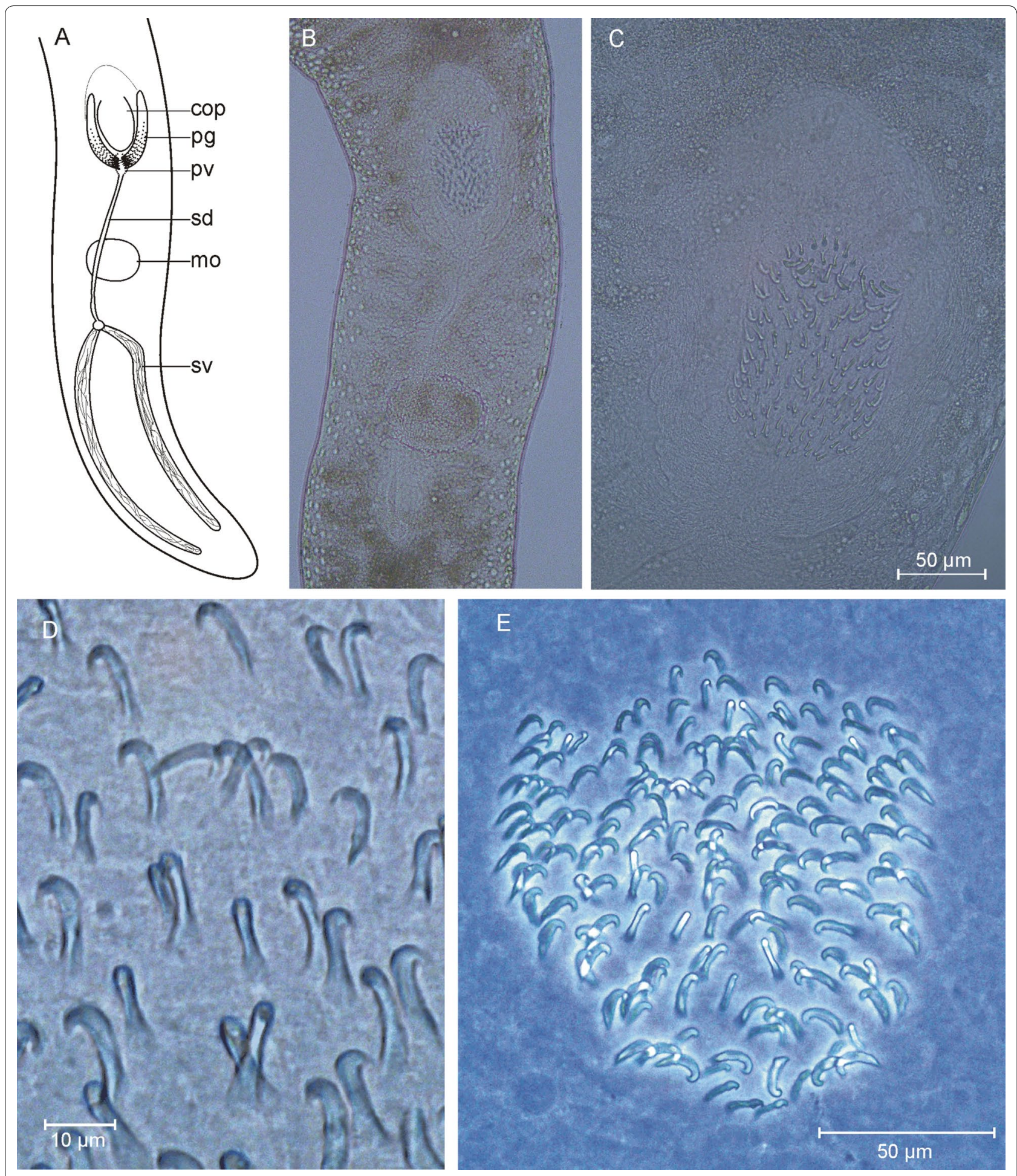

Fig. 7 Cirrifera paraculeata. A, B organization, rear end. C-E Sclerotic apparatus 
spines robust, numerous, 7-15 $\mu \mathrm{m}$ long, without a basal plate, with a strongly curved tip.

Description Very slender organisms, adults 8-10 mm long and $200-250 \mu \mathrm{m}$ in diameter. Live specimens may stretch even longer with a diameter only slightly wider than the pharynx, i.e. about $200 \mu \mathrm{m}$. Body whitish with numerous yellowish epidermal glands. Brain encapsulated and far frontal; statocyst frontal of the brain. The pharynx is spherical and positioned in the end of the middle third of the body.

General arrangement of the reproductive system as usual in the genus: numerous testes follicles in lateral rows from the brain to some $1 \mathrm{~mm}$ before the pharynx, paired germaries about $0.5 \mathrm{~mm}$ before the pharynx, and vitellaries laterally from the brain to the copulatory organ. The common genital pore lies ventrally in the beginning of the last sixth of the body, with the copulatory organ directly frontal of the pore. Caudally the genital atrium extends to a very striking spherical muscular organ about $100 \mu \mathrm{m}$ in diameter.

The paired seminal vesicles are very long, laterally in the last tenth of the body. They unite to the common seminal duct that is also very long, crosses the muscular organ dorsally and enters the copulatory bulb (prostatic vesicle) together with the distal part of prostatic glands. The prostatic vesicle is a slight swelling of the ejaculatory duct; from live observation it seems to be outside the copulatory bulb.

The cirrus spines are abundant (200-300) and arranged as a rather regular cylinder of $120-130 \mu \mathrm{m}$ length and 80-90 $\mu \mathrm{m}$ diameter. Individual spines are 7-15 $\mu \mathrm{m}$ long, with smaller spines in the proximal and distal sections of the cirrus and larger ones in the centre. All spines are rather robust, lack a basal plate, and have a strongly curved tip.

Discussion The genus Cirrifera includes three species with an unpaired seminal vesicle (C. boletiformae Sopott, 1972, C. dumosa Sopott, 1972, and C. genitoductus Jouk, Martens and Schockaert, 2007) and four species with paired seminal vesicles (C. aculeata (Ax, 1951), C. cirrifera Sopott, 1972, C. sopottehlersae Noldt and Jouk, 1988, and C. xanthoderma Riser, 1981). C. paraculeata belongs to the latter group. Among these species, a caudal extension of the genital atrium with a strongly muscular organ (a female atrium according to Martens and Schockaert [35]) is only reported for C. aculeata and the new species although the 'atrial diverticulum' in C. sopottehlersae (Noldt and Jouk, 1988) may be equivalent to that. Thus, C. paraculeata seems to be closely related to C. aculeata and both species co-occurred in the type locality. Both species differ in the shape of the cirrus spines (slender, weakly curved, and with a basal plate in C. aculeata against robust, without a basal plate, and with a strongly curved tip in C. paraculeata). In addition, C. paraculeata lacks the large bifid cirrus spine typical for C. aculeata, and it lacks spines in the muscular organ.

\section{Boreocelis fragilis n. sp. (Figs. 8, 9)}

Localities Subtidal medium to coarse sand of Lister Ley, the southward branch of the tidal inlet to Sylt-Rømø bight. (1) Coarse sand, $3.5 \mathrm{~m}$ water depth $\left(55.0414^{\circ} \mathrm{N}\right.$, $008.4796^{\circ} \mathrm{E}, 12 \mathrm{Sep} 2017,1$ individual). (2) Type locality: Medium sand, $10 \mathrm{~m}$ water depth $\left(55.0216^{\circ} \mathrm{N}, 008.4580^{\circ} \mathrm{E}\right.$, 20 Nov 2017, 2 individuals). (3) Medium sand, $10 \mathrm{~m}$ water depth $\left(55.0225^{\circ} \mathrm{N}, 008.4586^{\circ} \mathrm{E}, 11 \mathrm{Dec} 2017,4\right.$ individuals).

Material Live observations on 7 individuals, including drawings and photographs; four whole mounts, one designated holotype (AWI Sylt P2018-201) and three paratypes (AWI Sylt P2018-202 to AWI Sylt P2018-204).

Etymology Coverslip pressure during microscopical inspection caused three out of the seven individuals studied to autotomize the pre-cerebral frontal section of the body. The species name refers to this fragility.

Diagnosis Species of Boreocelis with a sclerotic apparatus consisting of a large clasp with paired extensions resembling a fishing-hook supporting the back of the copulatory organ and two shorter poles that are connected at their tips, thus forming a bifurcated clasp. The shorter poles also bear small extensions, and each of the extensions of the large element proceeds to the distal end of one of the shorter poles.

Description Unpigmented specimens up to $3 \mathrm{~mm}$ long, but body length is extremely variable, because the tail end may be contracted to less than $1 / 10$ of total body lengthor stretched out to become as long as the rest of the body. Thus, body length varied between 0.8 and $>2 \mathrm{~mm}$ in a single individual. The pre-cerebral frontal body section is longer than usual in monocelidids and looks strongly vacuolated. However, 3 of the 7 specimens studied alive autotomized the pre-cerebral body end during microscopical inspection; as a result, the statocyst came extremely close to the (remaining) frontal end. Individuals like this were also found during sorting (i.e. prior to microscopy); thus the length of the pre-cerebral front section is also highly variable in this species.

Big spindle to bottle-shaped rhabdite glands $(30 \mu \mathrm{m}$ long and $6-10 \mu \mathrm{m}$ in dimeter) occur over most of the body except in a narrow belt around the brain and in the very end of the tail. Because of the strong vacuolization, these rhabdite glands were most striking in the pre-cerebral section, but their number in this part of the body 


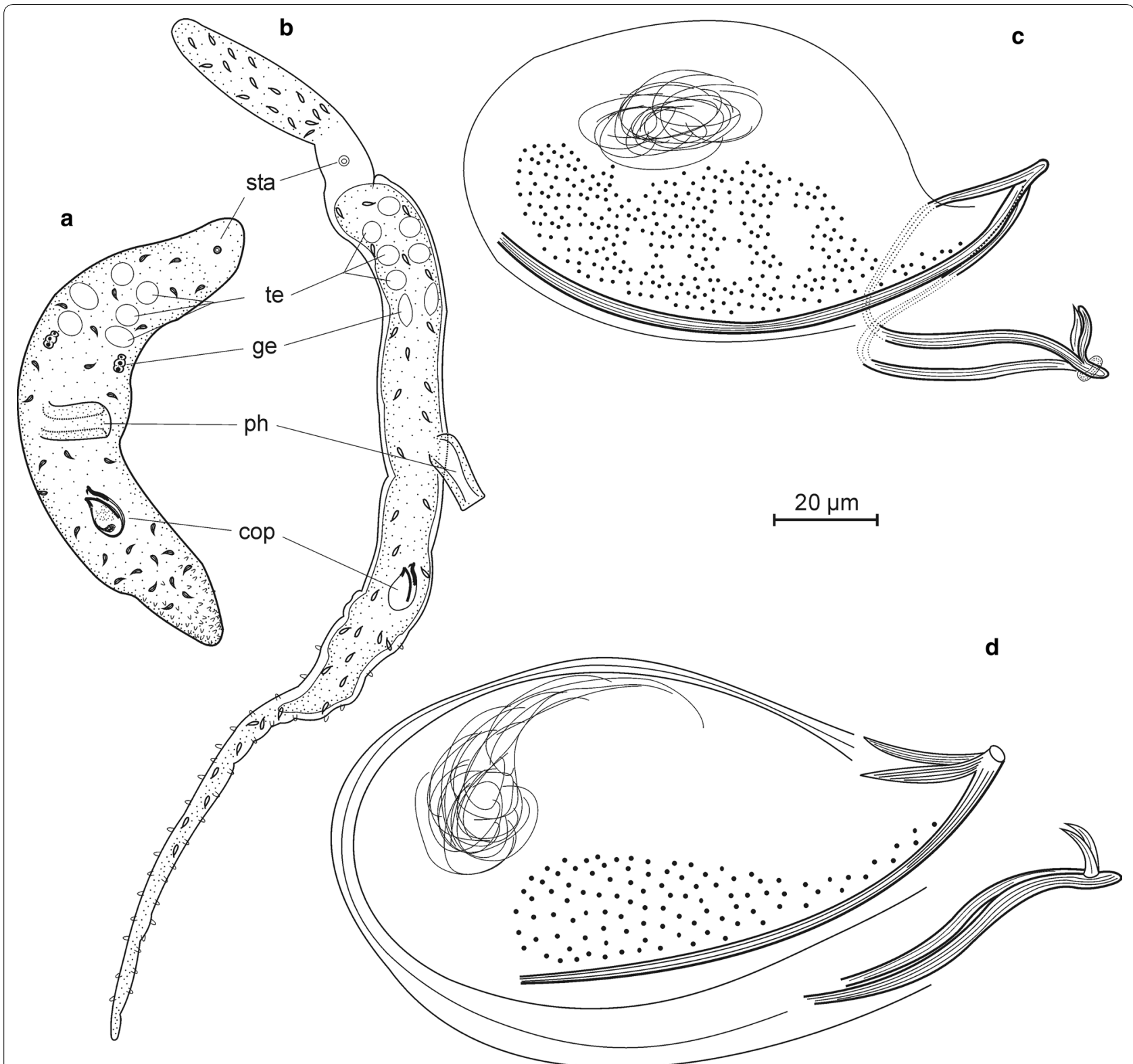

Fig. 8 Boreocelis fragilis. a, b organization; a contracted, frontal end recently autotomized; b moderately stretched, with frontal end complete. $\mathbf{c}$, $\mathbf{d}$ copulatory organ with sclerotic apparatus

varied (from none to 18) according to the state of regeneration of the frontal end after previous autotomy. Finger-shaped adhesive papillae are abundant in the caudal end.

Behind the brain, there are three pairs of testis follicles, followed by the paired germaries still well before the pharynx, which is situated in the middle of the body. The copulatory apparatus is situated behind the pharynx, well before the tail end. It is drop-shaped, some $110 \mu \mathrm{m}$ long and 50-60 $\mu \mathrm{m}$ wide, with a distinct layer of inner circular and outer longitudinal muscle fibres. These muscles enclose an unpaired sclerotic element, granular secretions, and sperm. Outer prostatic glands and the deferent duct leading sperm to the seminal vesicle could not be observed.

The sclerotic apparatus consists of three elements, a large one enclosed in the copulatory organ and two shorter poles. All three elements are constructed from several tightly fitting ledges. The large element (total length $100 \mu \mathrm{m}$ ) supports the back of the copulatory organ. 

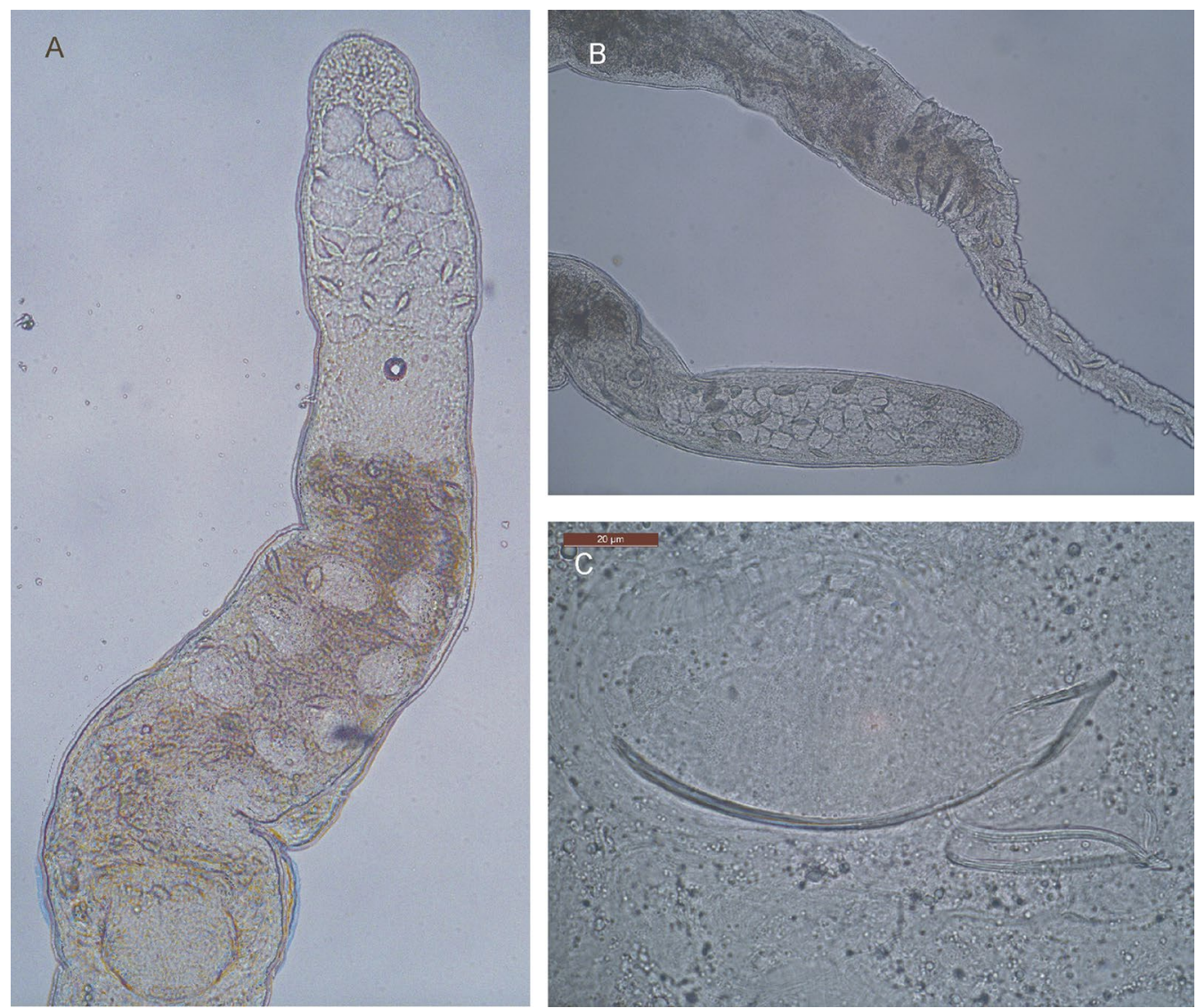

Fig. 9 Boreocelis fragilis. A frontal end. B frontal and rear end. c sclerotic apparatus

It is a slightly curved half-pipe with paired extensions (21 $\mu \mathrm{m}$ long) at the distal tip of the copulatory organ, thus resembling a fishing-hook. Only from the beginning of the lateral extensions to the distal tip the half-pipe is closed (or nearly so) to form an ejaculatory duct.

The shorter (about $47 \mu \mathrm{m}$ ) poles seem to be connected at their tips by a circular muscle thus forming a bifurcated clasp; they also bear small $(7 \mu \mathrm{m})$ extensions at their tip. The small and large sclerotic elements are not isolated from each other. Each of the extensions of the large element proceeds to the distal end of one of the shorter poles. The nature of this connection is not clear because the sclerotic part passes into the connecting fibres without a clear demarcation. Possibly the entire element is muscular with a sclerotic coating at the ends.

Discussion The general organization of the new species agrees well with the two species of Boreocelis known up to now, viz. B. filicauda Westblad, 1952 and B. urodasyoides Ax, 1963. All three species have a similar body shape with a long pre-cerebral head section with a transparent parenchyma and large rhabdites glands, a tail end that may be extremely extended, and a copulatory organ with a sclerotic apparatus consisting of three clasps, and other characters. But they clearly differ in the structure and size of the sclerotic apparatus. In B. filicauda the unpaired clasp is smaller $(128 \mu \mathrm{m})$ than the paired clasps $(185 \mu \mathrm{m})$ while in $B$. urodasyoides the unpaired clasp is larger $(78 \mu \mathrm{m})$ than the semi-circular paired ones (diameter of the semicycles $31 \mu \mathrm{m}$ ). With respect to the dimensions of the sclerotic elements $B$ fragilis is closer to the latter species, but the existence of distal extensions in all 3 clasps clearly differs from both known species.

\section{Postbursoplana noldti n. sp. (Fig. 10)}

Localities Type locality: Lister Ley, medium sand, water depth $10 \mathrm{~m}\left(55.0216^{\circ} \mathrm{N}, 008.4580^{\circ} \mathrm{E}, 20\right.$ and 27 Nov 2017, 4 individuals). Further localities: (1) Lister Ley, medium sand, water depth $7 \mathrm{~m}\left(55.0445^{\circ} \mathrm{N}, 008.4767^{\circ} \mathrm{E}, 1\right.$ individual on 25 Sep 2017 and 2 individuals on 22 Jan 2018). (2) List, fine sand next to the ferry landing, water depth $5 \mathrm{~m}$ (55.0151 $\mathrm{N}$ 008.4395E, 21 Aug 2017, 2 individuals). (3) Lister Ley, medium sand, water depth $6.5 \mathrm{~m}\left(55.0429^{\circ} \mathrm{N}\right.$, $008.4775^{\circ} \mathrm{E}, 25 \mathrm{Sep} 2017,5$ individuals). (4) Lister Ley, 


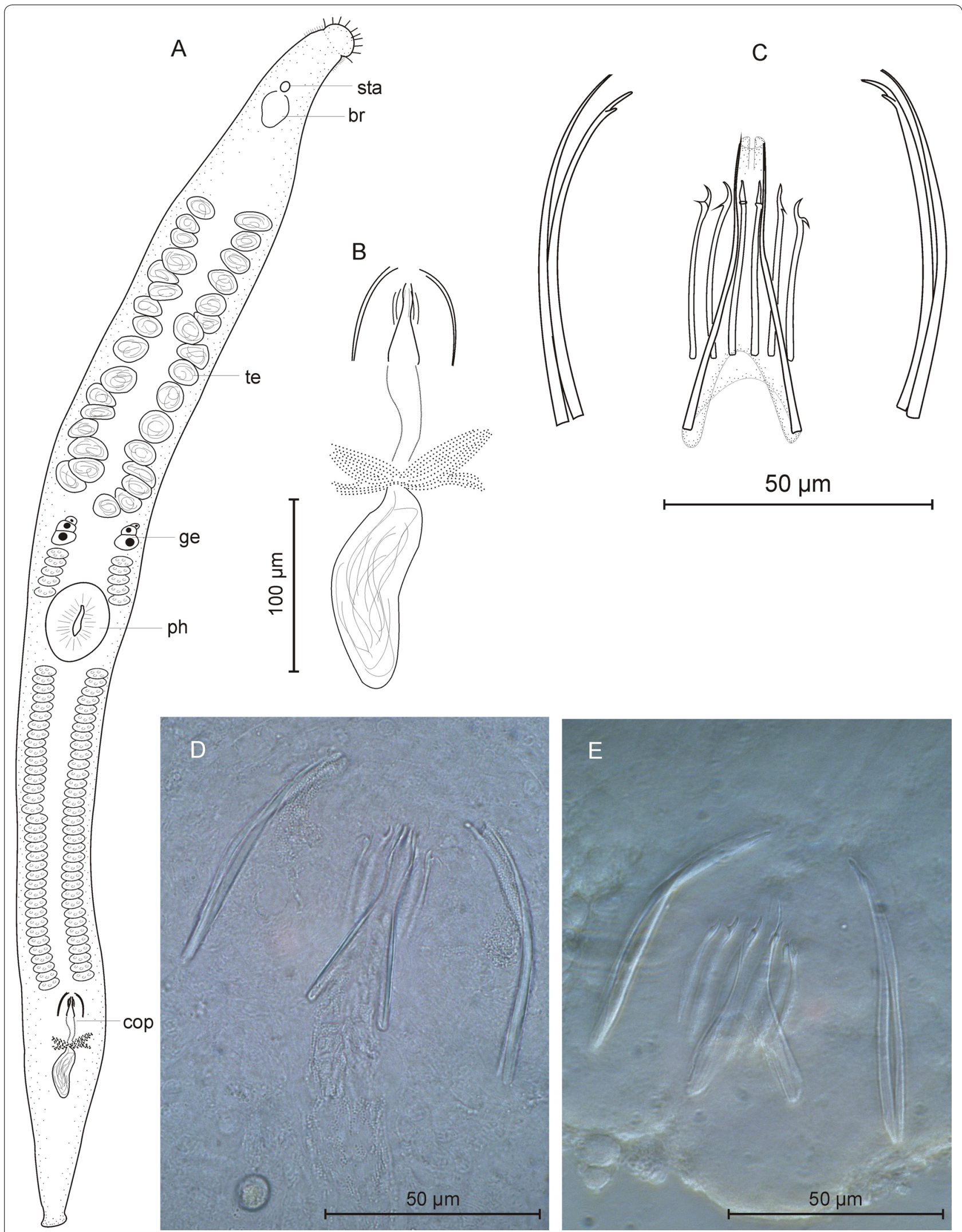

Fig. 10 Postbursoplana noldti. A organization. B copulatory organ. C-E sclerotic apparatus 
coarse sand, water depth $7 \mathrm{~m}\left(55.0458^{\circ} \mathrm{N}, 008.4760^{\circ} \mathrm{E}\right.$, Sep 2017, 2 individuals). (5) Lister Ley, medium sand, water depth $10 \mathrm{~m}\left(55.0225^{\circ} \mathrm{N} 008.4586^{\circ} \mathrm{E}, 12 \mathrm{Nov} 2017,20\right.$ individuals). (6) List Deep, medium sand, water depth $13 \mathrm{~m}$ $\left(55.0527^{\circ} \mathrm{N}, 008.4433^{\circ} \mathrm{E}, 19\right.$ Sep 1983 , leg. Uwe Noldt).

Material Live observations on some 20 individuals, including drawings and photographs. Additional drawings and photographs by Uwe Noldt from the 1980s. Ten whole mounts, one designated holotype (AWI Sylt P2018111), nine paratypes (AWI Sylt P2018-112 to AWI Sylt P2018-120).

Etymology The species was first encountered by Uwe Noldt during his studies on Kalyptorhynchia.

Diagnosis Extraordinarily large species of Postbursoplana with a male copulatory organ armed with a central group of six smaller hooks and two larger spines that support a delicate central funnel with a bulgy stem. The copulatory organ is accompanied by two pairs of slightly curved lateral spines with the opening of secretory glands between their tips.

Description Mature animals are 3-4 mm long, flattened, with typical otoplanid shape. Head with a ciliated furrow apically. The knob-shaped apical end bears about 50 slender sensory hairs of 30-40 $\mu \mathrm{m}$ length; single sensory hairs also occur laterally back to the brain. Ventral body ciliated from the head to the genital opening, adhesive papillae occur from the genital opening to the fan-shaped tail plate, which is densely packed with adhesive papillae. Rhabdoids are abundant but small, apparently arranged in three longitudinal double-rows. Pharynx in the beginning of the second body half, collar-shaped, some $250 \mu \mathrm{m}$ in diameter and oriented vertically.
Testes follicles (usually 16 pairs) in lateral rows before the pharynx, caudally followed by paired germaries and lateral rows of vitellaries that are interrupted besides the pharynx. Genital opening positioned in the beginning of the last $1 / 8$ of the body, concealed by the male copulatory organ. Male copulatory apparatus with a longish seminal vesicle caudally, well separated from the longish granular vesicle. A seminal bursa was only observed in a single individual; it was a single spherical bulb besides the seminal vesicle, connected to the genital atrium by a narrow duct that opens into the genital atrium at the caudal end.

Male copulatory apparatus with two pairs of lateral and a group of central spines. The lateral spines are rather long $(62-70 \mu \mathrm{m})$ and curved inwards, the outer pair with a tapering tip, the inner with a small bifurcation $7 \mu \mathrm{m}$ from the tip. Glands with granular secretions open between the distal tips of these lateral spines. The inner group contains eight spines of two types. Two larger $(49-53 \mu)$ spines are central in the group, with an inward bend before the distal third, giving the appearance of a slender funnel with a slightly bulgy stem. Ventrally this funnel is surrounded in a half circle by 6 shorter (28$32 \mu \mathrm{m})$ spines which are slightly curved and bear a triangular projection some $5 \mu \mathrm{m}$ from the tip. Phase contrast microscopy reveals that a delicate (? sclerotic) lamina stretches between the central 'funnel'-spines forming a functional funnel dorsally but eventually the funnel is not fully closed at the ventral side.

Discussion All Postbursoplana species have a male copulatory organ with a central group of 4-8 spines and (2 -) 4 lateral spines that are always slightly curved and longer than the median ones (Table 4). Species from the Mediterranean and from the Black Sea all have four or six spines in the central group while $P$. minima from the French Atlantic coast and P. noldti from the North Sea

Table 4 Body size and measures of the male sclerotic apparatus in Postbursoplana species

\begin{tabular}{|c|c|c|c|c|c|c|}
\hline & \multirow[t]{2}{*}{ Distribution } & \multirow{2}{*}{$\begin{array}{l}\text { Size at maturity } \\
\mathrm{mm}\end{array}$} & \multicolumn{2}{|c|}{ Lateral spines } & \multicolumn{2}{|c|}{ Spines in central bundle } \\
\hline & & & Number & Size range $(\mu \mathrm{m})$ & Number & Size range $(\mu \mathrm{m})$ \\
\hline P. noldti & North Sea & $3.0-4.0$ & 4 & $62-70$ & 8 & $28-53$ \\
\hline P. donoraticensis Meini, 2015 & Mediterranean & $1.6-1.8$ & 4 & $52-70$ & 6 & $46-55$ \\
\hline P. fibulata Ax, 1956 & Mediterranean & 1.0 & 4 & $56-60$ & 6 & Largest 48 \\
\hline P. macromystax Lanfranchi, 1969 & Mediterranean & $0.8-1.2$ & 4 & $42-47$ & 6 & $35-40$ \\
\hline P. minima Ax, 1956 & NE Atlantic & $0.4-0.5$ & 2 & 35 & 8 & Largest 35 \\
\hline $\begin{array}{l}\text { P. parafibulata Lanfranchi, Melai and } \\
\text { Meini, } 2010\end{array}$ & Mediterranean & $1.2-1.4$ & 4 & $55-73$ & 6 & $52-62$ \\
\hline P.pontica Ax, 1959 & Black Sea & $0.4-0.5$ & 4 & $40-42$ & 4 & $26-30$ \\
\hline P. propontica Ax, 1959 & Black Sea & $0.7-0.8$ & 4 & $45-50$ & 4 & 38 \\
\hline P. tyrrhenica Lanfranchi, 1969 & Mediterranean & $1.5-1.6$ & 4 & $44-48$ & 4 & 38 \\
\hline
\end{tabular}




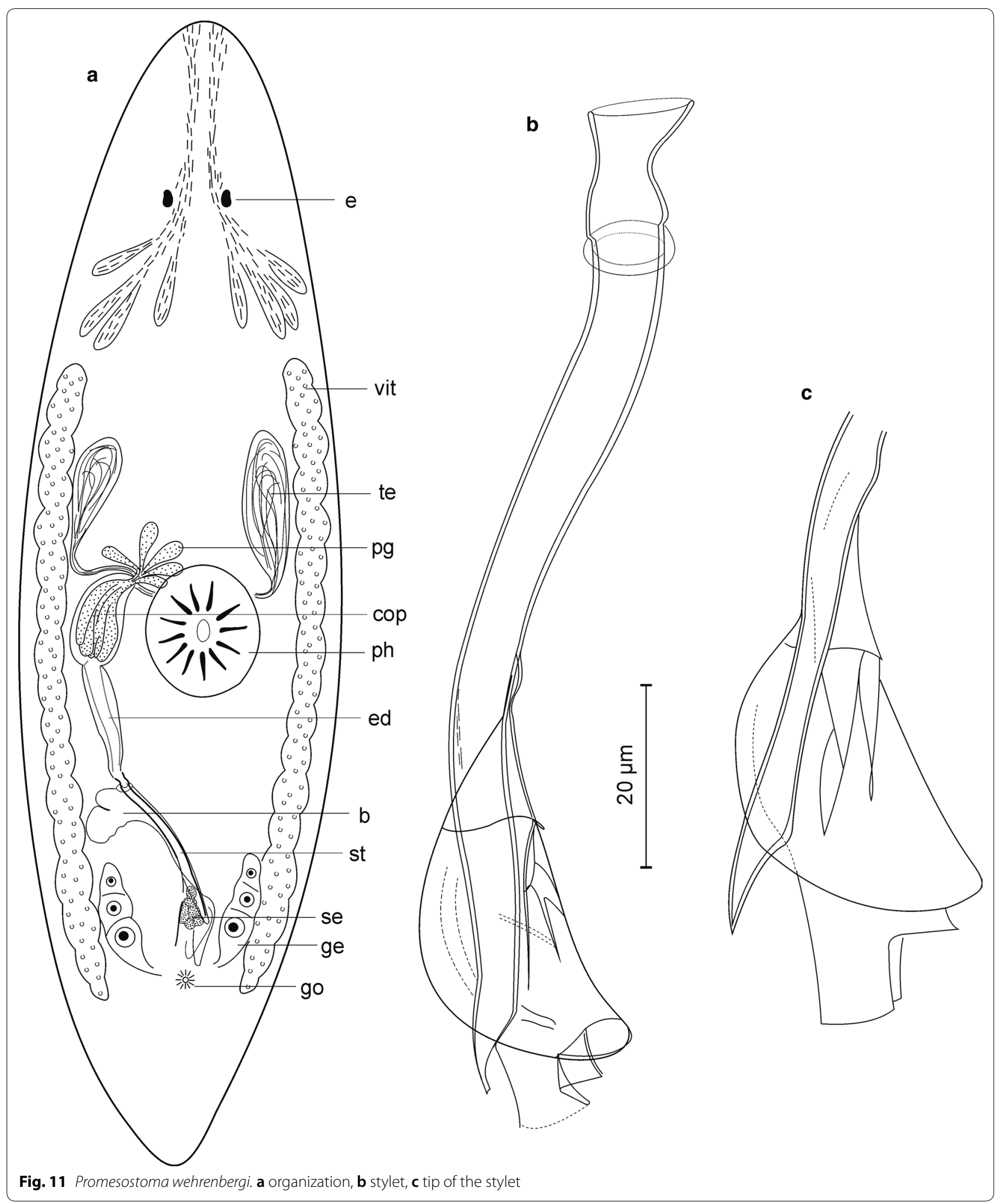


both have eight spines. $P$. noldti is far larger than all of the other species and it is characterized by a central group of spines consisting of 6 smaller hooks and 2 larger spines that support a delicate central funnel with a bulgy stem.

\section{Promesostoma wehrenbergi n. sp. (Figs. 11, 12)}

Localities Type locality: Lister Ley, coarse sand, water depth $7 \mathrm{~m}\left(55.0445^{\circ} \mathrm{N}, 8.4767^{\circ} \mathrm{E}, 25\right.$ Sep 2017, 1 individual). Previously also found in the adjoining List deep by Wehrenberg but there are no detailed records of localities.

Material Live observation, including drawings and photographs; further drawings by Christian Wehrenberg. Holotype is a whole mount AWI Sylt P2018-206.

Etymology The species was first recorded by Christian Wehrenberg.
Diagnosis Species of Promesostoma characterized by the lack of an external seminal vesicle, a copulatory organ with a weak muscular cover, and the structure of the stylet. This is a rather short $(110-112 \mu \mathrm{m})$ branched tube with a semi-circular flap at the distal end.

Description Unpigmented animals $0.7 \mathrm{~mm}$ long, tapering at both ends of the body. With paired eyes. Pharynx in the middle of the body or shortly behind. Testes, vitellaries and germaries paired, position as usual in the genus.

Besides the prostatic glands the deferent ducts seem to enter the copulatory organ directly; an external seminal vesicle was not observed. The copulatory organ is pear shaped, about $60 \mu \mathrm{m}$ long and $30 \mu \mathrm{m}$ wide, with a muscular cover that is distinct but rather weak for the genus. A long $(50 \mu \mathrm{m})$ ejaculatory duct connects the copulatory organ with the stylet.
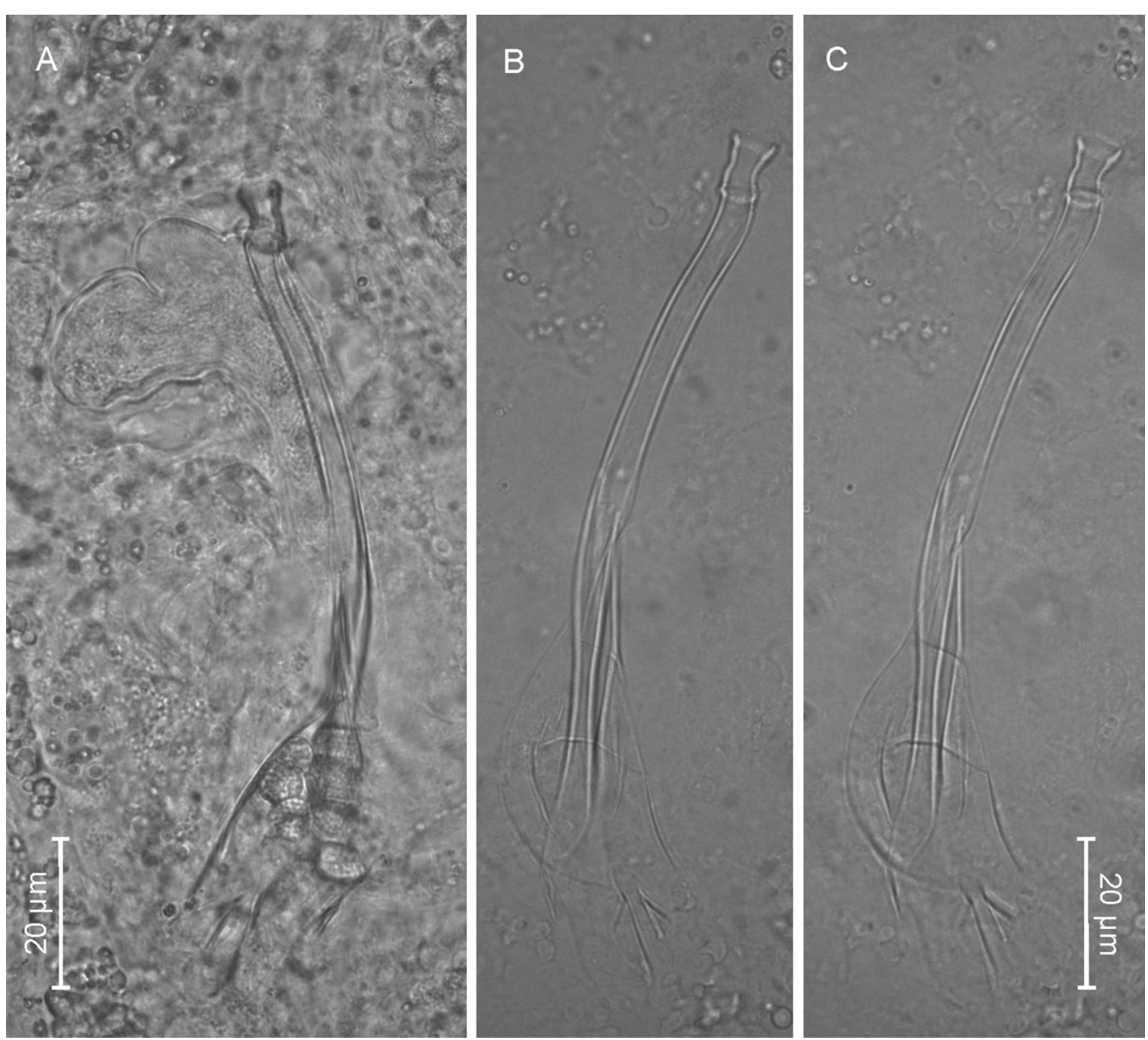

Fig. 12 Promesostoma wehrenbergi, stylet. A from life observation, B, C from whole mount 
The stylet is a rather short $(110-112 \mu \mathrm{m})$ branched tube with a semi-circular flap at the distal end. Proximally it starts with a funnel shaped opening of $3.5 \mu \mathrm{m}$ (up to $7 \mu \mathrm{m}$ according to measurements by Wehrenberg). The sphincter follows at a distance of $8 \mu \mathrm{m}$ from the proximal opening. Behind the sphincter, the stylet is a rather straight tube of $4 \mu \mathrm{m}$ inner diameter for about half of its length. At $45 \mu \mathrm{m}$ from the proximal opening, the stylet branches into two parts. Only one of the branches can be followed to the distal tip, the other one is only weakly hardened and partly concealed by a semi-circular flap (about $48 \mu \mathrm{m}$ long and $19 \mu \mathrm{m}$ wide). It is not clear whether this flap is a part of the stylet or part of the male genital channel.

In live material, $8-10$ roundish vesicles $5-6 \mu \mathrm{m}$ in diameter and consisting of fine granules were seen beneath the flap (Fig. 11a). After fixation these vesicles could no longer be seen (Fig. 11b, c). Presumably, this is the glandular organ observed in quite a number of Promesostoma species in the distal part of the male genital canal, once more challenging the nature of the semi-circular flap.

The bursa is a rather small $(17 \times 30 \mu \mathrm{m})$ bag with a striking notch in its frontal wall. It was filled with sperm to about half the stylet length.

Discussion The genus Promesostoma now comprises $>40$ species differing in stylet length and morphology. Only 4 species have a branched stylet and potentially form a sub-group of species with $P$. wehrenbergi: $P$. balticum, $P$. bipartitum, $P$. cochleare, and $P$. paracochlearis. These species differ in total stylet length and position of the branch (Table 5) as well as the shape of the stylet tips. The semi-circular flap in the distal part of the stylet is unique to $P$. wehrenbergi in this group though a similar structure occurs in the unbranched stylet of P. digitosa Ax, 1995.

Table 5 Stylet sizes in Promesostoma species with a branched stylet

\begin{tabular}{|c|c|c|c|}
\hline & $\begin{array}{l}\text { Total stylet } \\
\text { length }(\mu \mathrm{m})\end{array}$ & $\begin{array}{l}\text { Position } \\
\text { of stylet } \\
\text { branch }\end{array}$ & Sources \\
\hline P. balticum Luther, 1918 & $55 / 135$ & at $1 / 3$ length & Luther [36] \\
\hline P. bipartitum Ax, 1956 & 80 & at $1 / 2$ length & $A x[37]$ \\
\hline P. cochleare Karling, 1935 & $\begin{array}{l}140-155 \\
(120-130)^{*}\end{array}$ & at $^{1} / 4$ length & $\begin{array}{l}\text { Karling [38], } \\
\text { Luther [36], } \\
\text { *Ax [39] }\end{array}$ \\
\hline P. paracochlearis Ax, 1952 & $210-233$ & at $^{1} / 4$ length & $A x[39]$ \\
\hline P. wehrenbergi n. sp. & $110-112$ & at $^{1} / 2$ length & This paper \\
\hline
\end{tabular}

Ptyalorhynchus oculatus n. sp. (Figs. 13, 14)

Locality Type locality: North Sea, some $10 \mathrm{~km}$ west of the island of Sylt $\left(55.0355^{\circ} \mathrm{N}, 008.2134^{\circ} \mathrm{E}\right)$. Fine sand, water depth $14 \mathrm{~m}$.

Material Nine individuals studied alive, including drawings and photographs. Four whole mounts, one designated holotype (AWI Sylt P2018-211), three paratypes (AWI Sylt P2018-212 to AWI Sylt P2018-214).

Etymology This is the first species in the genus equipped with eye pigmentations.

Diagnosis Species of Ptyalorhynchus with pigmented eyes, characterized by a rim-shaped cirrus with three groups of spines, small $(2-3 \mu \mathrm{m})$ spines in the centre of the rim and larger $(5-12 \mu \mathrm{m}$ and $20-30 \mu \mathrm{m})$ spines in the edges.

Description Unpigmented slender specimens, free swimming up to $1.8 \mathrm{~mm}$ in length and $0.15 \mathrm{~mm}$ in diameter. The front end tapers from brain to tip $(130 \mu \mathrm{m}$ at brain, $50-60 \mu \mathrm{m}$ at rostral end), the caudal end is conical. Without obvious adhesive papillae. The pharynx (diameter $90 \mu \mathrm{m}$ ) is situated in the mid of the body or in the very beginning of second half. With a pair of medium sized eyes in front of the brain. Frontal gland cells behind the brain, well developed.

The proboscis is elongate (in free swimming animals about $120 \mu \mathrm{m}$ long and $30 \mu \mathrm{m}$ in diameter), with a very small apex and a circle of eight longish glandular vesicles stretching over the entire proboscis length. Proboscis gland cells are highly developed (Fig. 13d) though the nature and function of the post-cervical complex could not be analysed from life observations.

Genital opening subterminally, copulatory organ in the last tenth of the body. The testes are paired, in free swimming animals longish (some $300 \mu \mathrm{m}$ ) in front of the pharynx or right testis in front of and left one besides the pharynx. The sperm in the testes as well as those in the seminal vesicles and bursa all have a striking pattern of very fine dots. Seminal vesicles paired, piriform.

The copulatory organ is ovoid and equipped with a weak muscle cover. Prostatic glands were seen outside the copulatory organ and prostatic vesicles inside. When the prostatic secretions are emptied, the proximal part of the copulatory organ looks strongly vacuolated. The distal part of the ejaculatory duct bears a rim-shaped cirrus with numerous fine $(2-3 \mu \mathrm{m})$ spines in the inner part of the rim. The rising edges of the rim carry larger spines, few very large ones $(20-30 \mu \mathrm{m})$ at one side and medium sized spines $(5-12 \mu \mathrm{m})$ at the other edge. The very large spines seem to be fused at their base. 

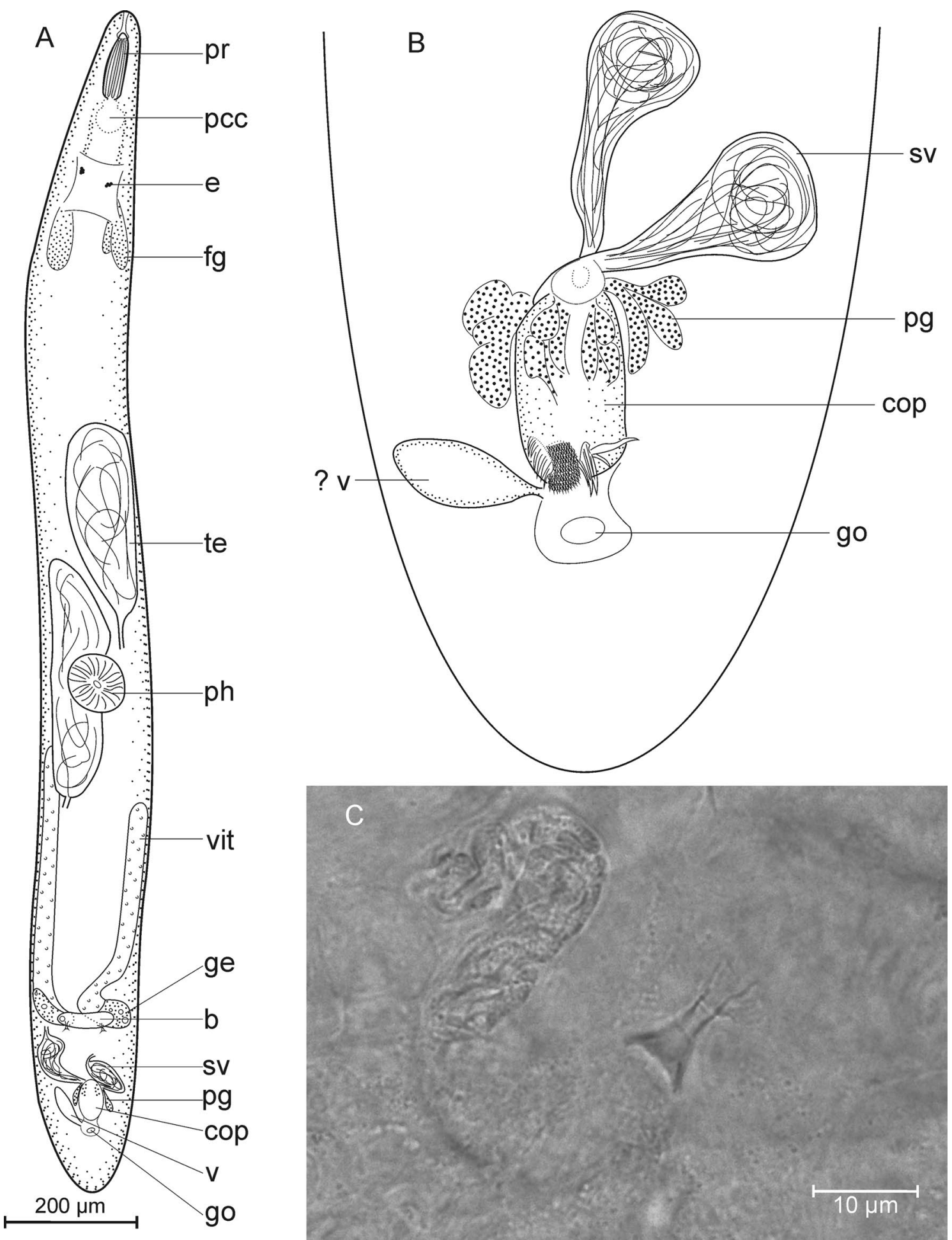

Fig. 13 Ptyalorhynchus oculatus. A, B organization, C bursal mouth piece

Paired germaries rostrally of the copulatory organ, fused to the vitellaries that stretch forth to the pharynx or slightly below. A rostral junction of the vitellaries was not observed. The copulatory bursa is situated between the copulatory organ and the germaries, equipped with paired cuticular mouth pieces of $12 \mu \mathrm{m}$ total length. The 

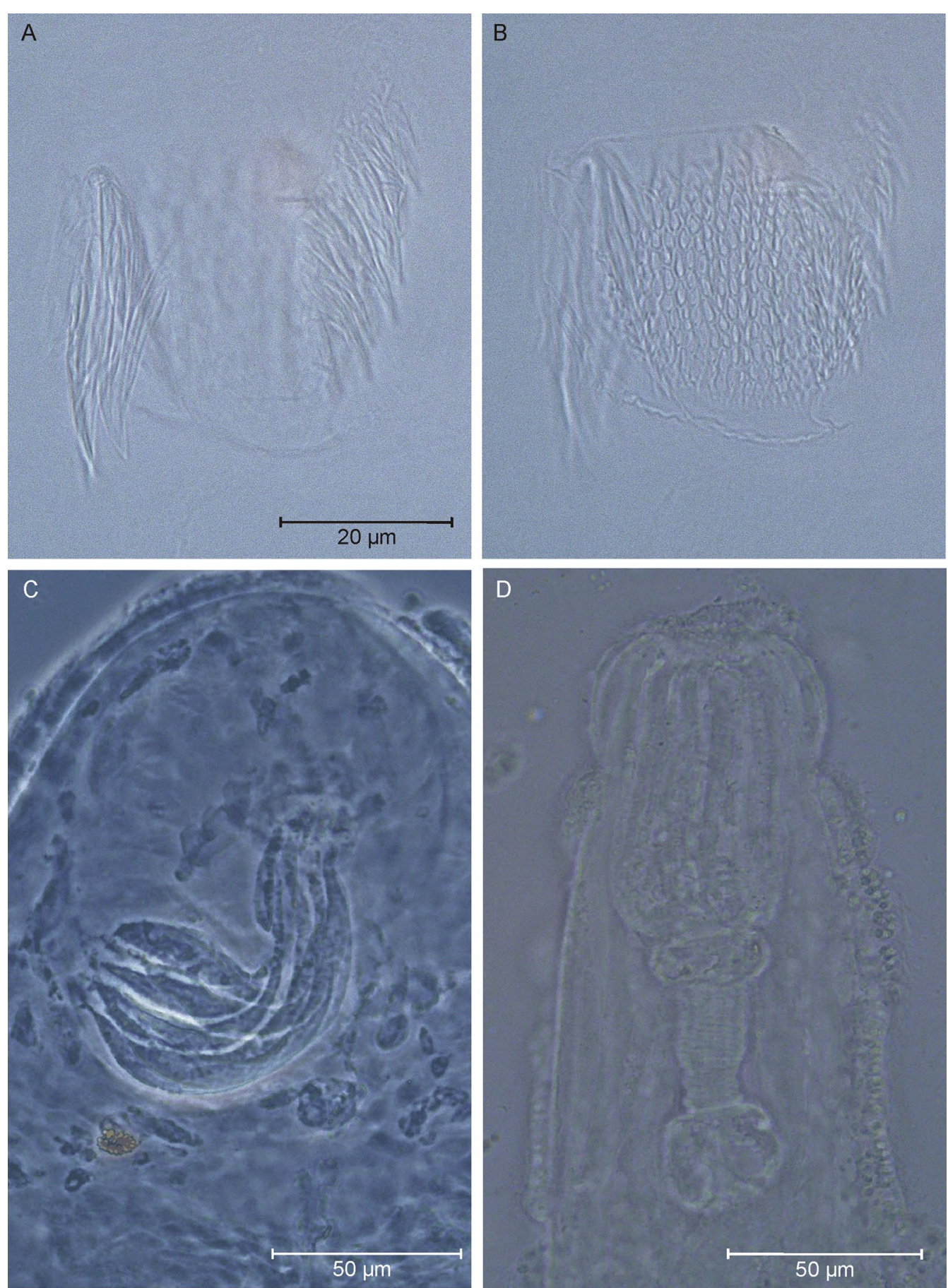

Fig. 14 Ptyalorhynchus oculatus. A, B cirrus spines, different focus. C proboscis, D proboscis with post-cervical complex

part oriented towards the germo-vitelloduct is funnelshaped and $7 \mu \mathrm{m}$ long (funnel diameter at opening $6 \mu \mathrm{m}$ ) while the part reaching into the bursa (with several roots) has a length of $5 \mu \mathrm{m}$. The genital atrium has a weakly muscular piriform bulge besides the copulatory organ, presumably functioning as a vagina.
Discussion P. oculatus fits the genus diagnosis but differs from the existing species in the arming of the cirrus: $P$. piger Brunet, 1973 bears a single group of small $(4-5 \mu \mathrm{m})$ spines, $P$. coecus Meixner in Ax, 1951 a proximal group of short $(6-8 \mu \mathrm{m})$ and a distal group of long $(24-35 \mu \mathrm{m})$ spines while $P$. oculatus has a rim-shaped cirrus with three 
groups of spines, small $(2-3 \mu \mathrm{m})$ spines in the centre and larger $(5-12 \mu \mathrm{m}$ and $20-30 \mu \mathrm{m})$ spines in the edges. In addition, only $P$. oculatus has eye pigmentations.

\section{Acrorhynchides canaliculatus n. sp. (Figs. 15, 16)}

Localities Type locality: Rantum, high tide level, muddy accretion zone of the salt marsh grown with Spartina (54.8464 ${ }^{\circ} \mathrm{N} 008.2994^{\circ} \mathrm{E}, 6$ June 2017, 1 individual). Previous localities: (1) Kampen, muddy accretion zone grown with Spartina $\left(54.9678^{\circ} \mathrm{N} 008.3527^{\circ} \mathrm{E}\right.$, July 1983,1 individual); (2) Morsum, muddy accretion zone without vegetation $\left(54.8543^{\circ} \mathrm{N} 008.4308^{\circ} \mathrm{E}\right.$, Sept 1982,2 individuals); (3) Kampen, lower salt marsh with Puccinellia maritima $\left(54.9678^{\circ} \mathrm{N} 008.3525^{\circ} \mathrm{E}\right.$, July 1982,4 individuals); (4) Kampen, muddy Spartina marsh $\left(54.9671^{\circ} \mathrm{N} 008.3531^{\circ} \mathrm{E}\right.$, June 1983, 1 individual).

Material Live observations including drawings and photographs. Since the intended holotype was lost in preparation the series of photographs taken on this specimen is declared holotype and deposited in the Pangaea data repository (https://doi.pangaea.de/10.1594/PANGAEA.895829).

Etymology The species name refers to the channelshaped stylet positioned among the cirrus spines.

Diagnosis Species of Acrorhynchides with a nearly straight and relatively short $(48-54 \mu \mathrm{m})$ stylet and cirrus spines are all equal-sized.

Description Colourless specimens of $1 \mathrm{~mm}$ body length; both ends gently rounded, pharynx in the end of the frontal and genital opening in the beginning of the caudal third of the body. With paired eyes; proboscis as usual in Polycystididae.

Vitellaries and germaries separate and paired, testes and seminal vesicles paired. Copulatory organ $(180 \mu \mathrm{m}$ long and $75 \mu \mathrm{m}$ wide) with a strong muscular cover and largely filled with prostatic secretions in twisted tubes, external prostatic glands relatively small. Distal part of the copulatory organ with a stylet shaped like a nearlyclosed channel (length 48-54 $\mu \mathrm{m}$, proximal diameter $6 \mu \mathrm{m}$, distal diameter $7 \mu \mathrm{m})$. The stylet extends into the male genital channel, which is equipped with cirrus spines over a length of some $75 \mu \mathrm{m}$. It is not clear from live observations whether the entire diameter of the male genital channel bears spines; at least in some individuals the spines seemed to be limited to more or less triangular dorsal and ventral sections. The spines all have a circular basal plate and are $3-5 \mu \mathrm{m}$ long.

The male genital channel opens distally of the cirrus into the genital atrium, together with the paired germovitelline ducts, a seminal receptacle, the uterus, glands with coarse secretions, and a lobate vesicle filled with very fine secretions, probably the copulatory bursa. The exact positions of the openings of these organs and ducts could not be traced in live inspection.

All localities are in the transition zone between upper intertidal mud flats and muddy salt marshes. In this belt salinity typically is in the polyhaline range on the island of Sylt.

Discussion Besides A. styliferus, this is the second Acrorhynchides species with a stylet. Both species differ in the size and shape of the stylet (137-156 $\mu \mathrm{m}$ and strongly curved in A. stylifera and 48-54 $\mu \mathrm{m}$ long and nearly straight in A. canaliculatus). In addition, the cirrus spines are all similar in A. canaliculatus while there is a group of larger teeth in A. styliferus.

\section{Dactyloplana n. gen}

Etymology The genus name refers to the finger-like projections of the proboscis hooks, from the Greek word for finger.

Diagnosis Cheliplaninae with proboscis hooks bipartite into an unbranched basal and a branched distal part.

Description Cheliplaninae with typical characters of the family: proboscis with side pieces and post-rostral bulb, one pair of proboscis hooks without denticles, no eyes. One adhesive girdle at the rear end, cylindrical pharynx anteriorly. Single testis, paired seminal vesicles, male copulatory organ with cirrus. Proboscis hooks with an unbranched basal and a branched distal part.

Discussion Currently the family Cheliplaninae Schilke, 1970 combines four genera. All of them have a proboscis with a post-rostral bulb, proximal muscle tongues, and distal hooks. The hooks may (genus Cheliplanilla Meixner, 1938, and some species of Cheliplana de Beauchamp, 1927) or may not bear denticles (Archipelagoplana Noldt and Hoxhold, 1984, Baltoplana Karling, 1949, and most species of Cheliplana) but are all unbranched. Dactyloplana represent a new type of proboscis hooks with an unbranched basal and a branched distal part.

\section{Genus type Dactyloplana paradoxa (Noldt, 1989).}

\section{Further species Dactyloplana tridigitata n. sp.}

\section{Dactyloplana paradoxa (Noldt, 1989) nom. nov}

Cheliplana paradoxa was the first species of Cheliplaninae with distally divided proboscis hooks and Noldt [12] preliminary classified it with Cheliplana. Now the detection of Dactyloplana tridigitata indicates that there are 


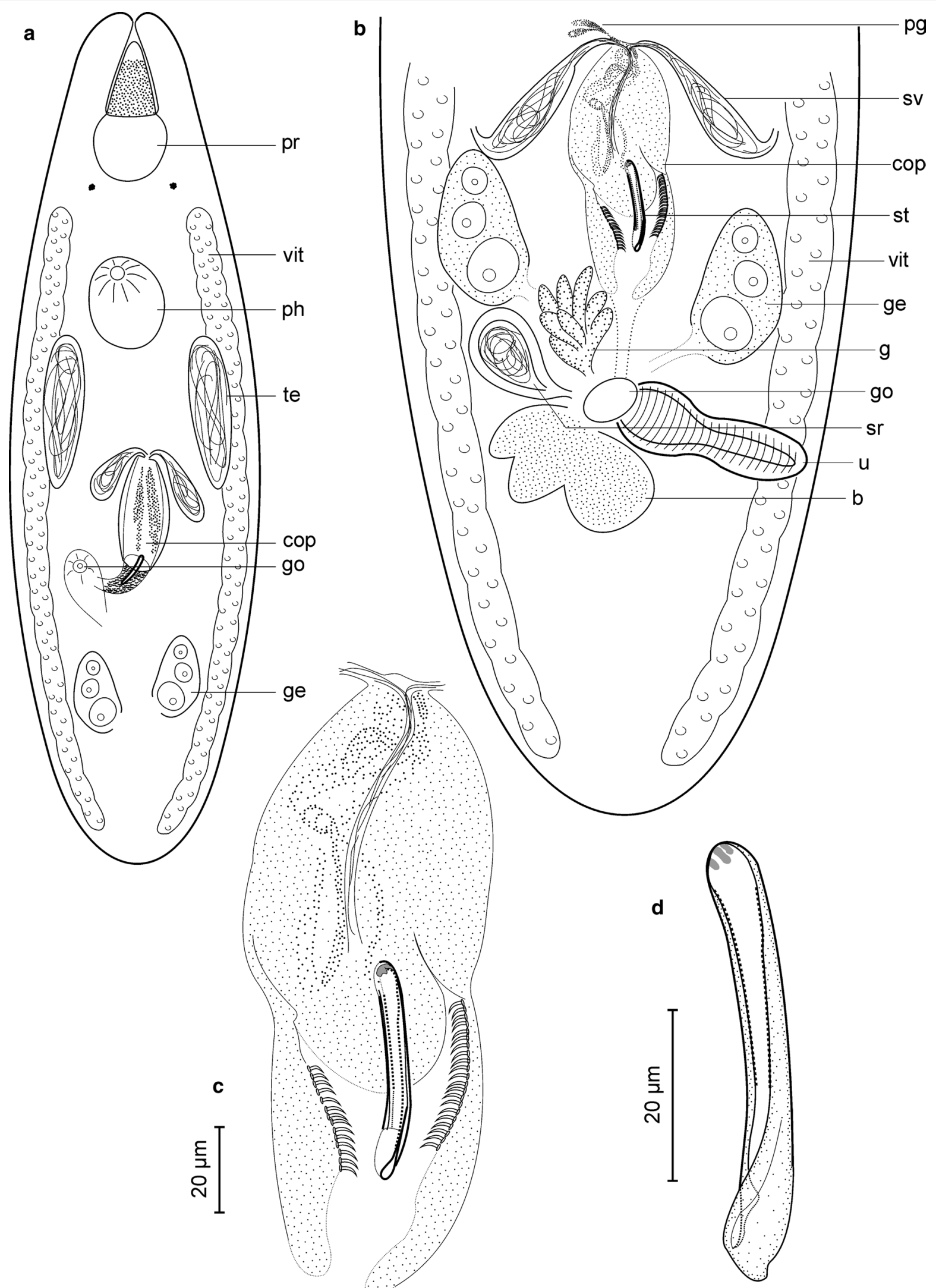

Fig. 15 Acrorhynchides canaliculatus. a, b organization; c copulatory organ; $\mathbf{d}$ stylet 

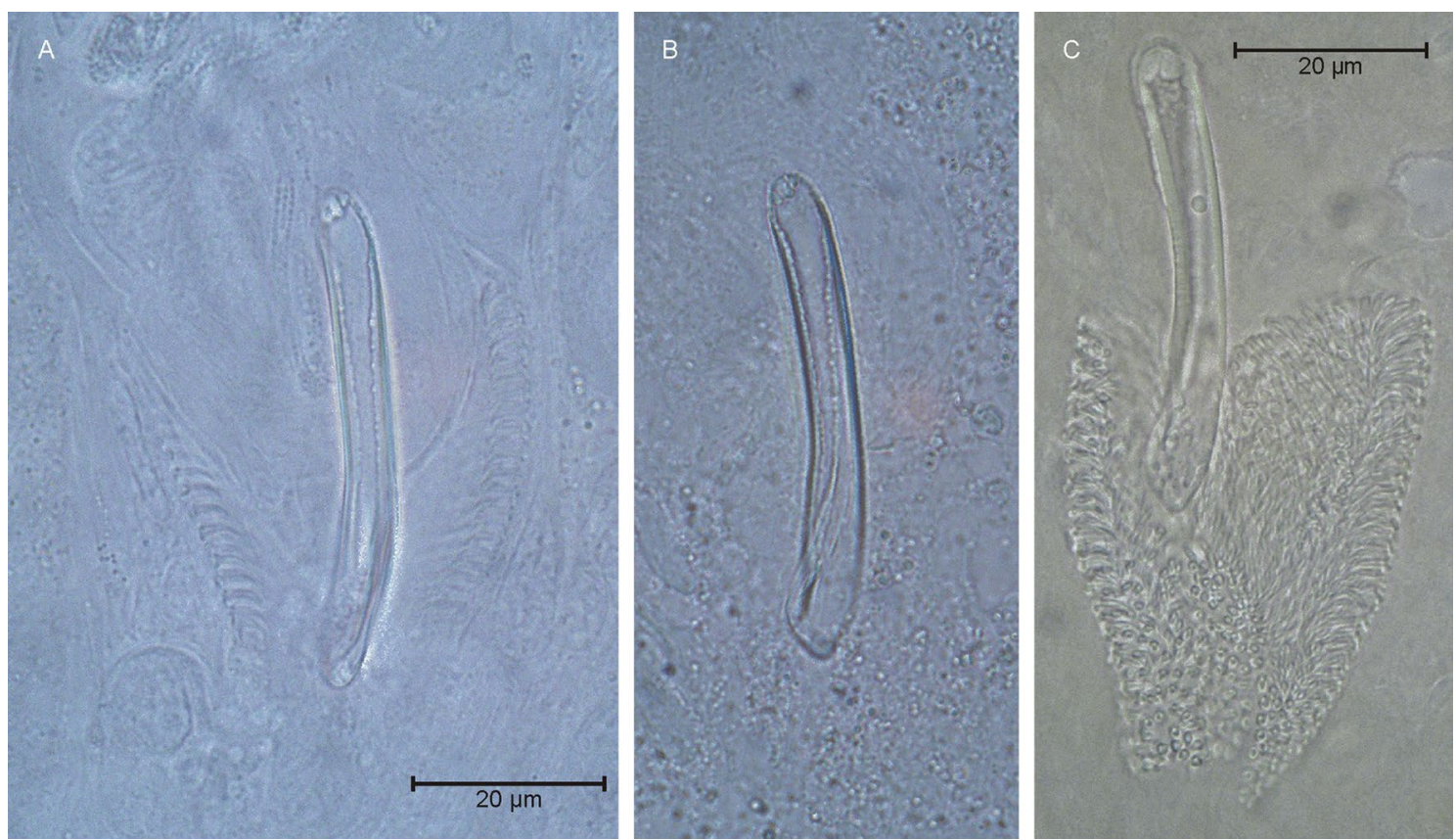

Fig. 16 Acrorhynchides canaliculatus, stylet. A, B from life observation, C from whole mount

more species with proboscis hooks that are undivided in the basal part and a divided tip. This new type of proboscis hook architecture justifies the creation of a new genus. Since Cheliplana paradoxa was the first species with that character, it is transferred to the genus Dactyloplana and declared the type species.

\section{Dactyloplana tridigitata n. sp. (Fig. 17)}

Localities (1) Type locality: Lister Ley, fine sand, $6 \mathrm{~m}$ water depth $\left(55.0365^{\circ} \mathrm{N} 008.4751^{\circ} \mathrm{E}, 18\right.$ Sep $2017 ; 2$ individuals). (2) Lister Ley, fine sand, $6 \mathrm{~m}$ water depth $\left(55.0347^{\circ} \mathrm{N}, 008.4726^{\circ} \mathrm{E} ; 20 \operatorname{Sep} 2017 ; 1\right.$ individual). (3) Lister Ley, fine to medium sand, $8 \mathrm{~m}$ water depth $\left(55.0272^{\circ} \mathrm{N}\right.$, 008.4617 ${ }^{\circ}$; 20 Nov 2017; 2 individuals).

Material Life observations on 5 individuals including drawings and photographs. Three whole mounts, one designated holotype (AWI Sylt P2018-208), two paratypes (AWI Sylt P2018-209 and AWI Sylt P2018-210).

Etymology The species name refers to the three fingerlike projections of the proboscis hooks.

Diagnosis Species of Dactyloplana with proboscis hooks consisting of a proximal straight unbranched part and a distal part divided into three finger-shaped processes.

Description Free swimming individuals $0.9-1.0 \mathrm{~mm}$ long with a reddish colour; mounted individuals 0.4-
$0.6 \mathrm{~mm}$ long. With a caudal adhesive girdle and a distal end with an annulated tail ( $60 \mu \mathrm{m}$ long). General organization as in the genus description.

The proboscis has a total length of 41-42 $\mu \mathrm{m}$ and consists of muscular proboscis lips (19-20 $\mu \mathrm{m})$ and the distal hooks $(22-23 \mu \mathrm{m})$; post-rostral bulb present. The hooks look like gloves with a long gauntlet (11-12 $\mu \mathrm{m}$ long, proximal diameter $4.0-4.5 \mu \mathrm{m}$, distally narrowing to $3.5-4.0 \mu \mathrm{m}$ ) and three finger-like spines distally (spine length $10-11 \mu \mathrm{m}$, with a basis diameter of $2.0-2.5 \mu \mathrm{m}$ and tapering to the pointed tip). A fourth smaller spine (3 $\mu \mathrm{m}$ long, basis diameter $1 \mu \mathrm{m}$ ) occurs in the proximal part of the gauntlet section, however, this is hard to see and was only observed in a single individual (Fig. 16a, b).

The copulatory organ is ovoid, $42 \mu \mathrm{m}$ long and $20 \mu \mathrm{m}$ in diameter (squeezed 45-50 $\mu \mathrm{m}$ long and 25-29 $\mu \mathrm{m}$ wide). The cirrus has total length of $27 \mu \mathrm{m}$, proximally shaped like a wide pipe ( $8 \mu \mathrm{m}$ diameter) obliquely cut off and distally like a sphere ( $14 \mu \mathrm{m}$ in diameter). The length of the cirrus spines ranged between 3-4 $\mu \mathrm{m}$ proximal and 6-7 $\mu \mathrm{m}$ distally. Genital opening caudal of the copulatory organ, further caudally a large seminal receptacle.

Dactyloplana tridigitata lives in fine to medium subtidal sand and was only found in cores penetrating deeper than $10 \mathrm{~cm}$ into the sediment, together with a number of other red-coloured platyhelminths (Pseudoschizorhynchoides ruber, Subulagera rubra, Diascorhynchus rubrus). Presumably it is specialised for larger sediment depth or low oxygen conditions and the red 


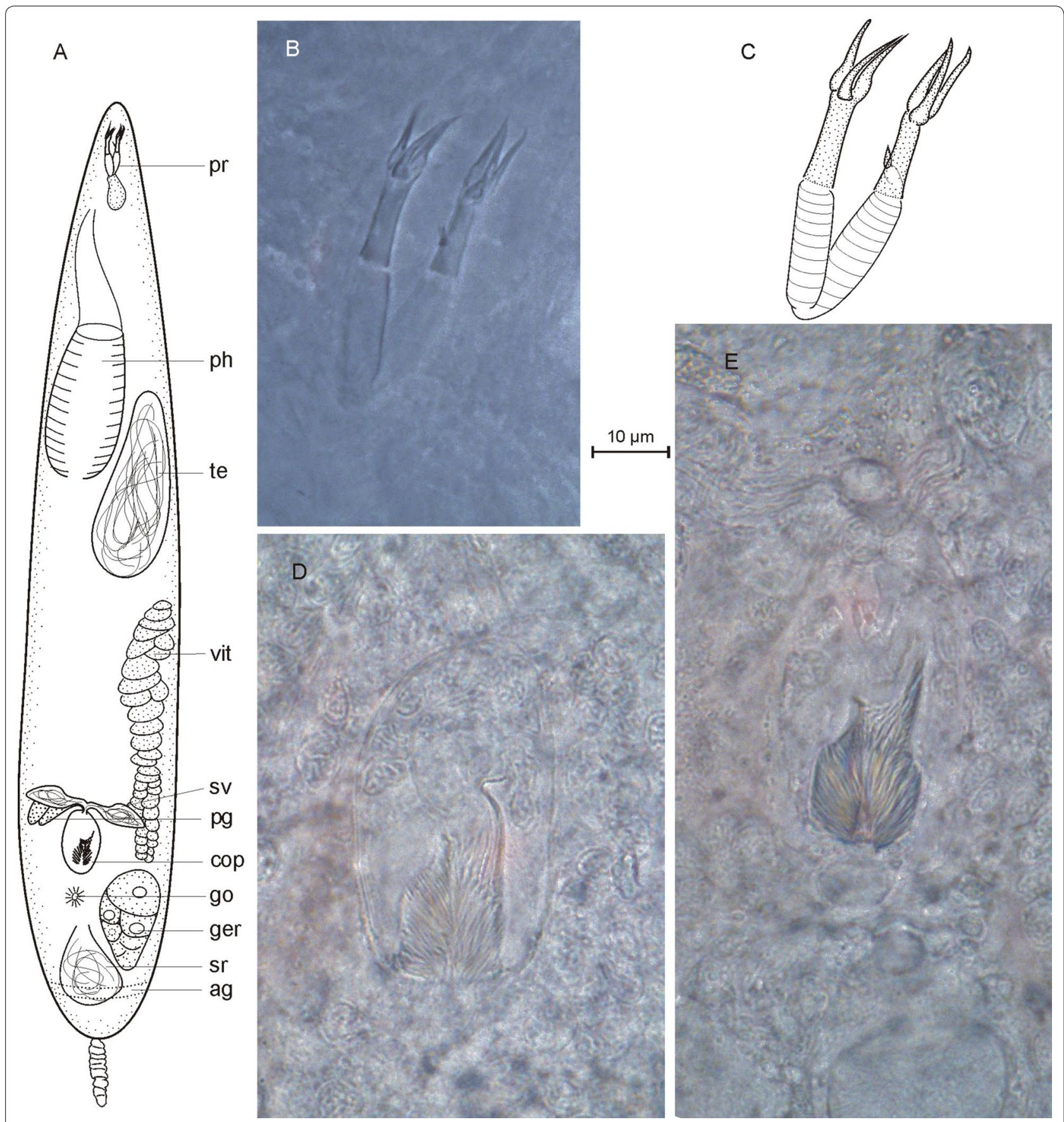

Fig. 17 Dactyloplana tridigitata. A organization (schematic); B, C proboscis with muscular tongue and distally tripartite hooks; D, E copulatory organ with cirrus

stain is oxygen-binding hemerythrin allowing oxygendependent organisms to temporarily enter low-oxygen or anoxic habitats [40].

Discussion D. tridentata differs from D. paradoxa (Noldt, 1989) in the shape of the branched part of the proboscis hooks (solid thorns in D. paradoxa versus slender spines in $D$. tridigitata) and in the number of distal branches (2 versus 3 per hook). In addition, $D$. tridigitata has an annulated tail end. A further difference might be the reddish colour in $D$. tridigitata but 
D. paradoxa is only known from whole mounts and an eventual colouration might have been lost.

Recently, Takeda and Kajihara [41] described a new cheliplanid genus Freddius characterized by proboscis hooks articulated with moveable nails, with side pieces, and with two additional lateral nails at the base of one of the hooks. Dactyloplana lacks the latter additional nails. In addition, the distal projections of the proboscis hooks ('nails' in Takeda and Kajihara [41]) in Freddius tricaudatus are described to be moveable. From previous life observations, the distal articles do not seem to be movable in the North Sea species, although the slight swelling in the proximal part of the distal articles might function as insertions for muscles. Thus, the genera Freddius and Dactyloplana are likely to be closely related.

\section{Additional file}

Additional file 1: Table S1. 'New data': sampling details and species composition in the cores evaluated for this study. Table S2: 'Subtidal Sylt': list of subtidal Platyhelminth species recorded around the island of Sylt including undescribed species. Table S3: 'Valid species Sylt': Platyhelminth species recorded around Sylt Island, including all tidal levels; valid species only. Table S4: 'All species Sylt': Platyhelminth species recorded around Sylt Island, including unidentified and undescribed species found during this study, according to tidal levels. Table S5: 'European species': Valid marine Platyhelminth species recorded from the ecoprovinces 'Northern European Seas', 'Lusitania', and 'Mediterranean'.

\section{Abbreviations}

ag: adhesive girdle; b: bursa; br: brain; cop: copulatory organ; e: eyes; ed: ejaculatory duct; fg: frontal glands; g: glands; ge: germary; go: genital opening; gvd: germo-vitello-duct; mo: muscular organ; pcc: post-cervical complex; pg: prostatic glands; ph: pharynx; pr: proboscis; pv: prostatic vesicle; sd: seminal duct; se: secretions; sg: shell glands; sr: seminal receptacle; st: stylet; sta: statocyst; sv: seminal vesicle; te: testes; v: vagina; vit: vitellary.

\section{Authors' contributions}

The author read and approved the final manuscript.

\section{Acknowledgements}

Thanks are due to Karsten Reise and two anonymous reviewers for valuable comments on an earlier draft of the ms.

\section{Competing interests}

The author declares that there is no competing interests.

\section{Availability of data and materials}

The datasets generated during the current study are available in Additional file 1.

\section{Consent for publication}

Not applicable.

\section{Ethics approval and consent to participate}

This study does not involve human participants, human data or human tissue. The studies on animals followed all applicable international, national, and institutional guidelines for the care and use of animals.

\section{Funding}

This study was funded by the author's home institute (Alfred Wegener Institut Helmholtz Zentrum für Polar- und Meeresforschung, Wattenmeerstation Sylt, Hafenstr. 43, 25992 List, Germany) and did not involve third-party funding. The institute did not influence the design of the study and collection, analysis, interpretation of data, or writing the manuscript.

\section{Publisher's Note}

Springer Nature remains neutral with regard to jurisdictional claims in published maps and institutional affiliations.

Received: 3 July 2018 Accepted: 6 November 2018

Published online: 10 November 2018

\section{References}

1. Giere O. Meiobenthology. The microscopic motile fauna of aquatic sediments. Berlin: Springer; 2009.

2. Heip C, Herman R, Vincx M. Subtidal meiofauna of the North Sea: a review. Biol Jb Dodonaea. 1983;51:116-70.

3. Schockaert ER. Turbellarians. In: Hall GS, editor. Methods for the examination of organismal diversity in soils and sediments. Wallingford: CAB International; 1996.

4. Armonies W, Reise K. Faunal diversity across a sandy shore. Mar Ecol Prog Ser. 2000;196:49-57.

5. Huettel M, Ziebis W, Forster S. Flow-induced uptake of particulate matter in permeable sediments. Limnol Oceanogr. 1996;41:309-22.

6. Armonies W. Freilebende Plathelminthen in supralitoralen Salzwiesen der Nordsee: Ökologie einer borealen Brackwasser-Lebensgemeinschaft. Microfauna Marina. 1987;3:81-156.

7. Hellwig M. Ökologie freilebender Plathelminthen im Grenzraum WattSalzwiese lenitischer Gezeitenküsten. Microfauna Marina. 1987;3:157-248.

8. Dittmann S, Reise K. Assemblage of free-living Plathelminthes on an intertidal mud flat in the North Sea. Microfauna Marina. 1985;2:95-115.

9. Reise K. Free-living Platyhelminthes (Turbellaria) of a marine sand flat: an ecological study. Microfauna Marina. 1984;1:1-62.

10. Scherer B. Annual dynamics of a meiofauna community from the'sulfide layer' of a North Sea sand flat. Microfauna Marina. 1985;2:117-61.

11. Wehrenberg C, Reise K. Artenspektrum und Abundanz freilebender Plathelminthes in sublitoralen Sänden der Nordsee bei Sylt. Microfauna Marina. 1985:2:163-80.

12. Noldt U. Kalyptorhynchia (Plathelminthes) from sublittoral coastal areas near the Island of Sylt (North Sea). I. Schizorhynchia. Microfauna Marina. 1989;5:7-85.

13. Noldt U. Kalyptorhynchia (Plathelminthes) from sublittoral coastal areas near the Island of Sylt (North Sea). II. Eukalyptorhynchia. Microfauna Marina. 1989;5:295-329.

14. Ruiz-Trillo I, Riutort M, Littlewood DT, Herniou EA, Baguña J. Acoel flatworms: earliest bilaterian metazoans, not members of Platyhelminthes. Science. 1999:283:1919-23.

15. Achatz JG, Chiodin M, Salvenmoser W, Tyler S, Martinez P. The Acoela: on their kind and kinships, especially with nemertodermatids and xenoturbellids (Bilateria incertae sedis). Org Divers Evol. 2013;13:267-86.

16. Cannon JT, Vellutini BC, Smith J, Ronquist $F$, Jondelius U, Hejnol A. Xenacoelomorpha is the sister group to Nephrozoa. Nature. 2016;530:89-93.

17. Armonies W. Long-term change of meiofaunal species composition in a sandy beach, with description of 7 new species of Platyhelminthes. Helgol Mar Res. 2017;71:12. https://doi.org/10.1186/s10152-017-0492-0.

18. Reise K. Tidal flat ecology. Berlin: Springer; 1985.

19. Gätje C, Reise K. Ökosystem Wattenmeer. Austausch-, Transport- und Stoffumwandlungsprozesse. Berlin: Springer; 1998.

20. Spalding MD, Fox HE, et al. Marine ecoregions of the world: a bioregionalization of coastal and shelf areas. Bioscience. 2007;57:573-83. https:// doi.org/10.1641/B570707

21. Reise K. Plathelminth diversity in littoral sediments around the island of Sylt in the North Sea. Prog Zool. 1988;36:469-80.

22. Ellenberg H. Vegetation Mitteleuropas mit den Alpen in ökologischer Sicht. Stuttgart: Ulmer; 1982. 
23. Pianka ER. Latitudinal gradients in species diversity: a review of concepts. Am Nat. 1966;100:33-46.

24. Schemske DW, Mittelbach GG. "Latitudinal gradients in species diversity": reflections on Pianka's 1966 article and a look forward. Am Nat. 2017;189:599-603.

25. Ehlers J, Gibbard PL. The extent and chronology of cenozoic global glaciation. Quat Int. 2007;164-165:6-20. https://doi.org/10.1016/j.quain t.2006.10.008

26. WoRMS Editorial Board: Discovery rate. http://www.marinespecies.org/ aphia.php?p=stats. Accessed 08 Mar 2018.

27. Zettler ML, Beermann J, Dannheim J, et al. An annotated checklist of macrozoobenthic species in German waters of the North and Baltic Seas. Helgol Mar Res. 2018;72:5. https://doi.org/10.1186/s10152-018-0507-5.

28. Scapa F, Cossu P, Lai T, Sanna D, Curini-Galletti M, Casu M. Meiofaunal cryptic species challenge species delimitation: the case of the Monocelis lineata (Platyhelminthes: Proseriata) species complex. Contrib Zool. 2016;85(2):123-45.

29. Scapa F, Cossu P, Sanna D, Lai T, Casu M, Curini-Galletti M. New insights on the genus Otoplana Du Plessis, 1889 (Platyhelminthes: Proseriata), with description of two new species from the Canary Islands. Mar Biodiv. 2017. https://doi.org/10.1007/s12526-017-0785-1.

30. Fonseca VG, Carvalho GR, Sung W, et al. Second-generation environmental sequencing unmasks marine metazoan biodiversity. Nat Commun. 2010;1:98. https://doi.org/10.1038/ncomms1095.

31. Sinniger F, Pawlowski J, Harii S, et al. Worldwide analysis of sedimentary DNA reveals major gaps in taxonomic knowledge of deep-sea benthos. Front Mar Sci. 2016;3:92. https://doi.org/10.3389/fmars.2016.00092.

32. Armonies W, Asmus H, Buschbaum C, Lackschewitz D, Reise K, Rick J. Microscopic species make the diversity: a checklist of marine flora and fauna around the Island of Sylt in the North Sea. Helgol Mar Res. 2018;72:11.
33. Ax P. Plathelminthes aus Brackgewässern der Nordhalbkugel. Stuttgart: Franz Steiner; 2008.

34. WoRMS Editorial Board: Coelogynopora Steinböck, 1924. http://www. marinespecies.org/aphia.php? $\mathrm{p}=$ taxdetails\&id=142460. Accessed $08 \mathrm{Mar}$ 2018.

35. Martens EE, Schockaert ER. Studies on the ultrastructure of the genital organs in Proseriata (Turbellaria). I. Cirrifera aculeata (Ax) (Coelogynoporidae). Zool Scr. 1985;14(2):81-90.

36. Luther A. Die Turbellarien Ostfennoskandiens III. Neorhabdocoela 1. Dalyellioida, Typhloplanoida: Byrsophlebidae und Trigonostomidae. Fauna Fenn. 1962;12:1-71.

37. Ax P. Turbellarien der Gattung Promesostoma von der französischen Atlantikküste. Kiel Meeresforsch. 1956;12:110-3.

38. Karling TG. Mitteilungen ueber Turbellarien aus dem Finnischen Meerbusen: 1. Dalyellia nigrifrons n. sp. 2. Promesostoma cochlearis n.sp. Mem Soc Fauna Flora Fenn. 1935;10:388-95.

39. Ax P. Turbellarien der Gattung Promesostoma von den deutschen Küsten. Kiel Meeresforsch. 1952;8:218-26.

40. Costa-Paiva EM, Schrago CG, Halanych KM. Broad phylogenetic occurrence of the oxygen-binding hemerythrins in bilaterians. Genome Biol Evol. 2017;9(10):2580-91. https://doi.org/10.1093/gbe/evx181.

41. Takeda N, Kajihara H. A new genus and five new species of Kalyptorhynchia (Platyhelminthes: Rhabdocoela) discovered in northern Japan. Spec Div. 2018;23:1-11. https://doi.org/10.12782/specdiv.23.1.
Ready to submit your research? Choose BMC and benefit from:

- fast, convenient online submission

- thorough peer review by experienced researchers in your field

- rapid publication on acceptance

- support for research data, including large and complex data types

- gold Open Access which fosters wider collaboration and increased citations

- maximum visibility for your research: over $100 \mathrm{M}$ website views per year

At BMC, research is always in progress.

Learn more biomedcentral.com/submissions 